\title{
Capital Flow Waves to and from Switzerland before and after the Financial Crisis
}

Pinar Yeşin ${ }^{a}$

JEL Classification: F21, F31, F32

Keywords: private capital flows, inflows, outflows, surges, stops, retrenchment, flight

\section{Introduction}

The global financial crisis of 2007-2008 led to massive swings in international capital flows. As Figure 1 shows, the sum of gross capital outflows from 172 countries declined from almost 21 percent of world GDP in 2007 to a mere 2 percent of world GDP in 2008. While swings in capital flows during recessions and crises had previously occurred, their sheer volatility during the global financial crisis was unprecedented (Milesi-Ferretti and Tille, 2011). Further, the upward swing in 2010 reversed again in 2011, and several years after the crisis, international capital flows remain well below their pre-crisis levels. By contrast, several countries experienced capital inflow surges owing to their high growth prospects and interest rate differentials after the financial crisis (Ahmed and Zlate, 2014).

Monitoring trends in capital flows has always been essential from a policymaker's perspective. On the one hand, international capital flows can foster growth and risk sharing through financial integration. On the other hand, they can exacerbate certain vulnerabilities, such as amplified business cycles, financial and macroeconomic instability, and banking, sovereign, or currency crises. Indeed, previous literature shows that large swings in international capital flows can have considerable effects on various macroeconomic and financial indicators,

a Swiss National Bank, Börsenstrasse 15, P.O. Box, CH-8022 Zürich, Switzerland, pinar.yesin@ snb.ch. I thank two anonymous referees, Adrien Alvero, Katrin Assenmacher, Irineu de Carvalho Filho, Andreas Fischer, Christian Grisse, seminar participants at the Swiss National Bank, and conference participants at the 2013 Conference of the Swiss Society of Economics and Statistics in Neuchatel and at the 2014 INFINITI conference on International Finance in Prato for their helpful comments and discussions. I also thank Adrien Alvero, Elisabeth Beusch, Elodie Moreau, and Laurence Wicht, who provided excellent research assistance at various stages of this project. Any remaining errors are my own. The views expressed in this paper are those of the author and do not represent those of the Swiss National Bank. 
such as inflation, asset prices, credit growth, and output (CALVO, 1998; REINhart and Reinhart, 2008; Cardarelli, Elekdag, and Kose, 2010; Furceri, Guichard, and Rusticelli, 2012; Tillmann, 2013). This finding holds for both advanced and emerging market economies. Accordingly, the massive swings in capital flows in recent years have created extraordinary challenges for policymakers across the globe.

Figure 1: International Capital Flows (\% of World GDP)

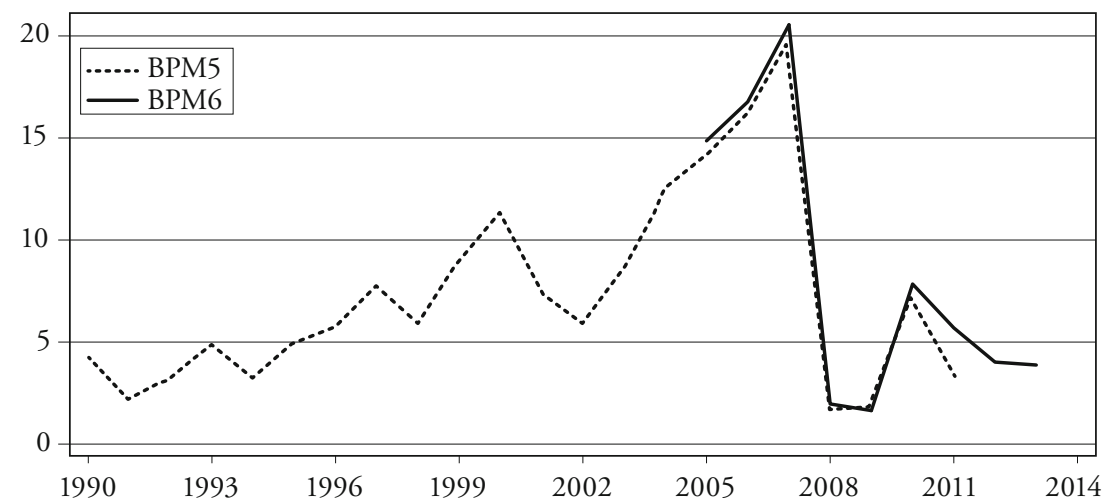

Sources: IMF BOPS, WDI, and author's calculations.

Note: International capital flows are defined as the sum of gross capital outflows from 172 countries in the International Monetary Fund's Balance of Payments Statistics (IMF BOPS) database. The IMF has two different data series for balance of payments statistics based on two different accounting standards: the formerly used BPM5 and the newly introduced BPM6 accounting standards. The BPM5 data extend only until 2008, though the author has data up to 2011 from an earlier vintage of the IMF database, which is no longer publicly available. The BPM6 data begin in 2005.

Against this backdrop, this paper aims to document the behavior of international capital flows before and after the global financial crisis with a special focus on Switzerland, a financial center with a small open economy. In particular, the paper documents the massive swings in international capital flows during the financial crisis across selected (groups of) countries and their diverse rebound experiences. The paper then analyzes quarterly data on capital flows to and from Switzerland between 2000:Q1 and 2014:Q2 and identifies waves of capital flows by using a simple statistical method. Through this analysis, periods of extreme capital flow movements—surges, stops, retrenchment, and flight—are identified. 
This paper makes two interesting contributions to the existing literature. First, it shows that because of the financial crisis, strong and long-lasting 'home bias' behavior is observed in many countries across the globe. However, the capital flows of financial centers were disproportionately affected by the financial crisis relative to those of other countries across the globe. Switzerland was no exception. Indeed, the paper shows that capital flows to and from Switzerland have become exceptionally muted and less volatile. Thus, the paper demonstrates that the retrenchment of capital flows across countries with significant international financial integration during the financial crisis (see, e.g., Milesi-Ferretti and Tille, 2011) might have become the new norm after the crisis. Furthermore, net capital flows to and from Switzerland exhibit significantly higher volatility since the global financial crisis, suggesting a decoupling of capital inflows and outflows. This finding contrasts with the long-run trends presented in previous literature, such as Broner et al. (2013) and Bluedorn et al. (2013). As Broner et al. (2013) show, capital inflows to and capital outflows from advanced economies have historically been positively correlated, resulting in small and stable net flows because of their opposing effects. As presented in this paper, the recent experience of Switzerland indicates that this positive correlation has decreased notably since the global financial crisis causing volatile net flows for Switzerland. BLUEDORN et al. (2013), by contrast, argue that capital flows across all economy groups historically tend to be fickle and that no differences exist between advanced and emerging market economies. The recent experience of financial centers presented in this paper provides a counterexample to this generalization. In fact, the paper shows that capital inflows to and outflows from financial centers registered a disproportionately large drop during the financial crisis and exhibited no recovery afterward.

The second contribution of this paper to the literature concerns the identification of capital flow waves for Switzerland. Separate analyses are conducted for capital flows initiated by foreigners and those initiated by domestic agents. Therefore, periods of surges and stops of capital inflows to Switzerland and periods of flight and retrenchment of capital outflows from Switzerland are identified separately. In so doing, this paper follows a recent but growing strand of literature on capital flows that has shifted its focus from net to gross capital flows, such as Kraay et al. (2005), Lane and Milesi-Ferretti (2007), Lane (2013), BlueDORN et al. (2013), and BRONER et al. (2013). Earlier literature on capital flows focused extensively on net capital flows and did not examine the type of investor underlying a capital flow wave. In fact, these studies implicitly assumed that foreign investors were the main drivers of extreme capital movements. However, this assumption is not necessarily accurate, as net capital flows are determined 
by the joint behavior of domestic and foreign investors. Furthermore, domestic and foreign agents are subject to different domestic and global conditions and considerations, and they may behave completely differently when they are faced with the same domestic and/or global shocks and policies. These behavioral differences between domestic and foreign agents may arise from asymmetric exposure to sovereign risk, home bias, more accurate information on the domestic economy, different hedging needs, better access to technology, among others. Thus, empirical analyses should acknowledge the individual behavior of domestic and foreign agents and should distinguish between capital in- and outflows. In addition, policymakers should identify whether capital flow waves are driven by domestic or foreign investors or a combination of both so that appropriate policy tools can be employed to maintain macroeconomic and financial stability when necessary.

Furthermore, the paper advances this line of research by analyzing the major (sub)components of capital in- and out-flows of extreme movements. There are two major benefits to studying (sub)components of capital flows for extreme movements. First, whenever an extreme movement occurs in gross capital flows, the type of investment flows underlying this movement can be detected. Second, one can unveil possible synchronization or desynchronization of capital flow waves in various investment types. In particular, the components/subcomponents of capital flows to and from Switzerland that are analyzed in this paper include private capital ${ }^{1}$, gross capital, direct investment, equity capital, reinvested earnings, debt instruments, portfolio investment, debt securities, equity securities, other investment, bank lending, other sectors lending, reserve assets, foreign currency investment, and derivatives.

The statistical analysis reveals that private capital inflows registered several surges and stops before and during the financial crisis. However, since 2008:Q2, only one period of surge and one period of stop have occurred. Similarly, private capital outflows from Switzerland registered several flight and retrenchment periods before and during the financial crisis. Yet, again, only one flight period has occurred since 2008:Q2. By contrast, net private capital flows show frequent abnormal values during the whole sample period.

Furthermore, there is a high degree of synchronization of capital flow waves in different (sub)components of capital flows before and during the financial crisis. However, extreme movements of private capital flows are largely driven by extreme movements of bank lending flows because they are coincident with

1 Gross capital flows to/from the private sector, excluding the central bank and the public sector. 
each other to a large extent during the sample period. In other words, capital flow waves in bank lending are driving the extreme movements of private capital flows in general. Extreme movements in other (sub)components of capital flows remain relatively small in gross flows to and from Switzerland.

The analysis also shows that some of the notable events that increased the uncertainty and volatility of global financial markets were coincident with capital flow waves to and from Switzerland. In particular, two abnormally low observations of net private capital flows were coincident with the euro area sovereign debt crisis in 2010:Q2 and the extended bailout of Greece in conjunction with the US debt-ceiling crisis in 2011:Q3. By contrast, the collapse of Lehman Brothers in 2008:Q3 and the speech by Ben Bernanke in 2013:Q2 on tapering were not coincident with extreme movements of net capital flows.

This paper is organized as follows. Subsection 2.1 describes the evolution of international capital flows before and after the financial crisis, and Subsection 2.2 describes the evolution of gross capital flows to and from Switzerland. Subsection 3.1 then describes the statistical method that is used to identify unusual behavior of capital flows, and Subsection 3.2 presents the findings. Section 4 concludes the paper.

\section{Capital Flows Before and After the Financial Crisis}

\subsection{International Capital Flows}

This subsection describes the evolution of international capital flows before and after the financial crisis. It aims to provide a context for the Swiss experience, which is discussed in the next subsection. Data for international capital flows are taken from the International Monetary Fund (IMF) Balance of Payments Statistics (BOPS) database and are based on the newly introduced BPM6 accounting standard. ${ }^{2}$ The annual data cover the period from 2005 to 2013. Capital flows data are normalized by nominal world GDP retrieved from the World Bank World Development Indicators (WDI) database to illustrate their macroeconomic relevance.

Table 1 summarizes the massive swings in international capital flows over time across selected (groups of) countries as a percentage of world GDP. It consists of

2 The IMF switched from the BPM5 to the BPM6 accounting standard in 2012. International balance of payments data based on the BPM6 accounting standard are not available prior to 2005, and international data based on the BPM5 standard are available only until 2008. 
three panels: the top panel presents gross capital outflows; the middle panel presents gross capital inflows, and the bottom panel presents net capital flows (i.e., the difference between gross capital outflows and gross capital inflows).

First, the top panel of Table 1 describes gross capital outflows from selected (groups of) countries. ${ }^{3}$ Positive values of capital outflows from a country indicate an increase in the respective country's foreign assets. Negative values, by contrast, indicate repatriation of an existing foreign investment back to the country. The top panel shows that before the financial crisis gross capital outflows from financial centers, i.e., economies that serve as hubs for international financial flows, were substantial. These financial centers are Belgium, Hong Kong, Luxembourg, Netherlands, Singapore, Switzerland, and the United Kingdom. ${ }^{4}$ Just prior to the financial crisis in 2007, capital outflows from financial centers were 7.3 percent of world GDP. Thus, financial centers accounted for almost 36 percent of total capital outflows. ${ }^{5}$ This result is striking in itself because only seven countries, six of which are small economies, were driving such a substantial volume of international capital outflows before the onset of the crisis. ${ }^{6}$ With the onset of the financial crisis, capital outflows decreased drastically from all (groups of) countries or even reversed in 2008 and 2009. There was a rebound of capital outflows from some countries afterwards, such as the USA and oil exporting countries. However, capital outflows from many advanced economies, particularly financial centers, continued to remain significantly lower than their pre-crisis levels. In fact, capital outflows from financial centers were still low at 0.5 percent of world GDP in 2013. Thus, financial centers accounted for less than 13 percent of total capital flows in 2013. Overall, the top panel of Table 1 reveals that capital flows from all countries were hit by the global financial crisis but that their recovery experiences differed considerably afterward. This finding contrasts with the findings of BLUEDORN et al. (2013), who argue that capital flows across all

3 Note that the sum of gross outflows from these (groups of) countries corresponds to the international capital flows series shown in Figure 1.

4 Notably, the definition of financial centers is tenuous. Here, I follow an extended definition of the IMF and classify six small economies with large financial markets as financial centers. In addition, I define the UK as a financial center because it has a substantial financial sector relative to its GDP and because it is regarded to be a hub for international financial flows by the World Bank. A vast majority of these countries' capital flows were in the form of crossborder banking flows before the onset of the financial crisis.

5 The UK significantly contributes to this number because of its sheer size, but it is not the main driver of this phenomenon.

6 The total GDP of financial centers was 8.8 percent of world GDP in 2007 and 6.8 percent of world GDP in 2012. The GDP of the UK was 5.1 percent of world GDP in 2007 and 3.4 percent of world GDP in 2012. 
Table 1: Capital Flows across Countries (\% of World GDP)

\begin{tabular}{|c|c|c|c|c|c|c|c|c|c|}
\hline & 2005 & 2006 & 2007 & 2008 & 2009 & 2010 & 2011 & 2012 & 2013 \\
\hline \multicolumn{10}{|l|}{ Gross capital outflows } \\
\hline Financial centers++ & 5.5 & 4.9 & 7.3 & -1.8 & -0.3 & 2.0 & 1.4 & 0.6 & 0.5 \\
\hline European periphery* & 1.9 & 1.9 & 1.7 & 0.4 & 0.1 & -0.1 & 0.0 & 0.1 & 0.0 \\
\hline Advanced countries+ & 1.7 & 1.9 & 1.7 & 0.4 & 0.5 & 0.7 & 0.3 & 0.1 & 0.0 \\
\hline USA & 1.2 & 2.7 & 2.8 & -0.5 & 0.2 & 1.5 & 0.7 & 0.2 & 0.9 \\
\hline Germany & 1.1 & 1.2 & 1.6 & 0.6 & 0.1 & 0.9 & 0.5 & 0.7 & 0.1 \\
\hline Oil exporters** & 0.9 & 1.2 & 1.3 & 1.2 & 0.1 & 0.6 & 0.9 & 0.9 & 0.7 \\
\hline China & 0.7 & 0.9 & 1.1 & 1.0 & 0.8 & 1.1 & 0.9 & 0.6 & 1.0 \\
\hline Japan & 0.3 & 0.2 & 0.5 & -0.1 & -0.5 & 0.2 & 0.1 & 0.2 & 0.1 \\
\hline Rest of the world*** & 1.5 & 1.8 & 2.4 & 0.9 & 0.6 & 1.1 & 0.9 & 0.6 & 0.7 \\
\hline Total & 14.9 & 16.8 & 20.5 & 2.0 & 1.6 & 7.8 & 5.7 & 4.0 & 3.9 \\
\hline \multicolumn{10}{|l|}{ Gross capital inflows } \\
\hline Financial centers++ & 5.3 & 4.7 & 7.1 & -1.8 & -0.4 & 1.7 & 1.2 & 0.5 & 0.3 \\
\hline USA & 2.7 & 4.2 & 3.9 & 0.7 & 0.5 & 2.1 & 1.4 & 0.8 & 1.4 \\
\hline European periphery* & 2.2 & 2.3 & 2.1 & 0.8 & 0.4 & 0.3 & 0.3 & 0.1 & -0.2 \\
\hline Advanced countries+ & 1.7 & 1.9 & 1.8 & 0.6 & 0.7 & 0.8 & 0.5 & 0.2 & 0.0 \\
\hline Germany & 0.8 & 0.8 & 1.1 & 0.2 & -0.2 & 0.6 & 0.2 & 0.3 & -0.4 \\
\hline China & 0.4 & 0.4 & 0.5 & 0.3 & 0.4 & 0.8 & 0.8 & 0.4 & 0.8 \\
\hline Oil exporters** & 0.3 & 0.4 & 0.7 & 0.4 & 0.0 & 0.3 & 0.2 & 0.3 & 0.2 \\
\hline Japan & 0.0 & -0.1 & 0.1 & -0.4 & -0.8 & -0.2 & -0.1 & 0.1 & 0.1 \\
\hline Rest of the world ${ }^{* * *}$ & 1.5 & 1.8 & 2.7 & 1.4 & 0.8 & 1.4 & 1.2 & 1.2 & 1.1 \\
\hline Total & 14.9 & 16.4 & 20.1 & 2.2 & 1.4 & 7.7 & 5.6 & 3.9 & 3.5 \\
\hline \multicolumn{10}{|l|}{ Net capital flows } \\
\hline Oil exporters** & 0.7 & 0.8 & 0.5 & 0.7 & 0.1 & 0.3 & 0.6 & 0.6 & 0.4 \\
\hline China & 0.3 & 0.5 & 0.7 & 0.7 & 0.3 & 0.3 & 0.2 & 0.2 & 0.1 \\
\hline Japan & 0.3 & 0.3 & 0.4 & 0.3 & 0.3 & 0.4 & 0.2 & 0.1 & 0.0 \\
\hline Germany & 0.3 & 0.4 & 0.5 & 0.4 & 0.3 & 0.2 & 0.3 & 0.4 & 0.4 \\
\hline Financial centers++ & 0.2 & 0.3 & 0.2 & 0.0 & 0.1 & 0.3 & 0.2 & 0.2 & 0.2 \\
\hline Advanced countries+ & 0.0 & -0.1 & 0.0 & -0.2 & -0.2 & -0.1 & -0.2 & -0.1 & -0.1 \\
\hline European periphery* & -0.3 & -0.4 & -0.4 & -0.5 & -0.3 & -0.4 & -0.3 & 0.0 & 0.1 \\
\hline USA & -1.5 & -1.5 & -1.1 & -1.2 & -0.3 & -0.7 & -0.7 & -0.6 & -0.5 \\
\hline Rest of the world ${ }^{* * *}$ & 0.0 & 0.0 & -0.3 & -0.6 & -0.1 & -0.3 & -0.3 & -0.5 & -0.4 \\
\hline Total & 0.0 & 0.3 & 0.5 & -0.2 & 0.2 & 0.1 & 0.1 & 0.1 & 0.4 \\
\hline
\end{tabular}

Source: IMF BOPS (BPM6), WDI, and author's calculations.

Note: + Australia, Canada, France, and Korea.

++ Belgium, Hong Kong, Luxembourg, Netherlands, Singapore, Switzerland, and the United Kingdom.

* Greece, Ireland, Italy, Spain, and Portugal.

** Algeria, Angola, Ecuador, Iraq, Kuwait, Libya, Nigeria, Norway, Qatar, Russia, Saudi Arabia, and Venezuela.

*** Rest of the world encompasses the remaining 140 countries. 
economy groups historically tend to be fickle and that the behavior of flows do not significantly differ across economy groups (advanced or emerging), despite the differences in policies across economies and over time.

The middle panel of Table 1 presents gross capital inflows to selected (groups of) countries. Positive values of gross capital inflows indicate an increase of the foreign liabilities of the listed countries, whereas negative values indicate repatriation. The middle panel shows that capital inflows to all countries decreased significantly or even reversed in 2008 and 2009. As is the case for capital outflows, the rebound experiences of capital inflows differed considerably across countries. In particular, capital inflows to financial centers show a disproportionately sharp drop and no significant recovery since the crisis. ${ }^{7}$ The middle panel of Table 1 shows that just before the financial crisis in 2007, capital inflows to financial centers were 7.1 percent of world GDP, accounting for 35 percent of total capital inflows. In 2013, however, they were quite low, at 0.3 percent of world GDP, accounting for less than 9 percent of total capital inflows. ${ }^{8}$

The bottom panel of Table 1 lists net capital flows to or from selected (groups of) countries. Net capital flows are calculated as the difference between gross capital outflows and gross capital inflows. Positive values indicate net capital outflows from a country, resulting in a current account surplus, whereas negative values indicate net capital inflows to a country, resulting in a current account deficit. The bottom panel shows that net capital flows around 2009 also exhibit a break in the trend for some of the selected countries, such as China, the USA, and the European periphery. Since 2009, net capital flows have decreased, in absolute value, for most of the selected countries. However, these breaks are much smaller than those observed for gross capital flows shown in the other panels of Table 1. This observation supports the view that gross capital flows must be studied separately to understand the different behavior between domestic and foreign investors.

In summary, Table 1 shows that investors exhibited 'home bias' behavior after the financial crisis, i.e., levels of new foreign investment by investors after the financial crisis tended to be lower than pre-crisis levels. In particular, capital flows to and from financial centers, as well as some advanced countries and countries in the European periphery, seem to have been disproportionately affected by the financial crisis relative to those of other countries.

7 Nevertheless, net capital flows to/from financial centers remained relatively stable before and after the crisis.

8 The discrepancies between total gross capital inflows and total gross capital outflows are due to errors and omissions of individual countries' balance of payments statistics. 


\subsection{Capital Flows to and from Switzerland}

In this subsection, the evolution of capital flows to and from Switzerland is presented. Data for Switzerland are taken from the Swiss National Bank's (SNB) balance of payments statistics and are based on the newly introduced BPM6 accounting standard. ${ }^{9}$ They are on a quarterly basis, expressed as a percentage of GDP, and cover the period from 2000:Q1 to 2014:Q2.

In the following figures and tables, the sample period is divided into three sub-periods: the pre-financial-crisis period, between 2000:Q1 and 2006:Q4; the financial crisis period, between 2007:Q1 and 2009:Q2 (shaded in the figures); and the post-financial-crisis period, between 2009:Q3 and 2014:Q2. The start and end quarters of the financial crisis sub-periods are chosen based on the crisis timeline published by the Federal Reserve Bank of St. Louis. ${ }^{10}$ These dates also reflect the changing behavior of capital flows to and from Switzerland with the onset of the financial crisis.

In addition, notable events that affected financial markets are indicated with vertical lines in the following figures to provide some context. These notable events significantly increased the uncertainty and volatility of global financial markets, as measured, for example, by sudden spikes in the Chicago Board Options Exchange's volatility index, VIX. These events were considered to trigger international capital flows with possible repercussions on financial markets. The notable events considered in this paper are the collapse of Lehman Brothers in 2008:Q3 [Lehman], the euro area sovereign debt crisis in 2010:Q2 [EA Crisis I], the extended bailout of Greece in conjunction with the US debt-ceiling crisis in 2011:Q3 [EA Crisis II], and the speech by Ben Bernanke on tapering in 2013:Q2 [Bernanke Tapering].

Furthermore, private capital flows to and from Switzerland rather than gross capital flows are depicted in this section. Gross capital flows consist of both private capital flows and public capital flows. Public capital flows are defined as flows that

9 In 2014, the Swiss balance of payments and international investment position data were aligned with the IMF's Balance of Payments and International Investment Position Manual, Sixth Edition, BPM6 (http://www.imf.org/external/pubs/ft/bop/2007/bopman6.htm). This version of the paper uses Swiss balance of payments data based on this new accounting standard. Quarterly data based on the BPM6 accounting standard are available from 2000:Q1 onward. An earlier version of this paper used data based on the previous BPM5 accounting standard. The general findings of the statistical analysis are robust to the choice of accounting standard. More information on the change in accounting standards in Switzerland can be found at http://www.snb.ch/en/iabout/stat/bpm6/id/stat_bpm6_uebersicht.

10 http://timeline.stlouisfed.org/pdf/CrisisTimeline.pdf starts with events in February 2007 and ends with events in July 2009. 
go to or emanate from the public sector, while private capital flows are defined as the residual. In particular, reserve accumulations by central banks are included in public capital flows. During normal times, and with a flexible exchange rate regime, public capital flows constitute a negligibly small part of gross capital flows. However, since 2009:Q2, public capital flows have been sizeable for Switzerland because of exchange rate interventions by the SNB, which have resulted in reserve accumulations. Therefore, studying gross capital flows would provide a biased view of (domestic) investor behavior for Switzerland. Therefore, this section focuses on private capital flows only. Corresponding figures depicting gross capital flows are included in Appendix A for completeness of analysis.

Figure 2: Private Capital Inflows to Switzerland (\% of GDP)

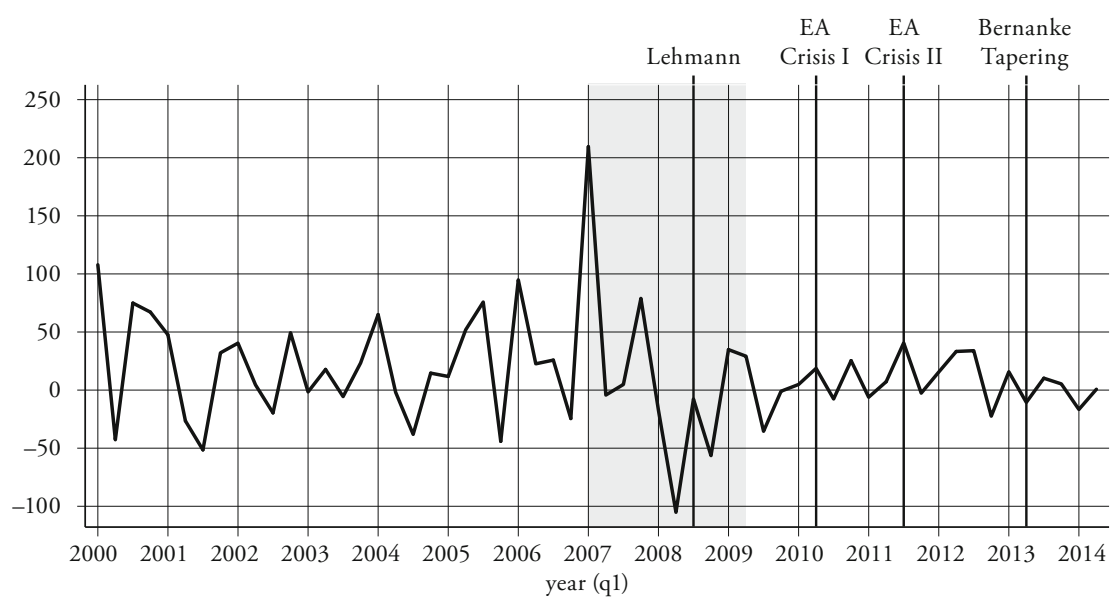

Source: SNB and author's calculations.

Note: The shaded area corresponds to the crisis period from 2007:Q1 to 2009:Q2. Four vertical lines indicate notable events during the sample period. These events are the collapse of Lehman Brothers in 2008:Q3, the bailout of Greece in 2010:Q2 amid the euro area sovereign debt crisis, the extended bailout of Greece in 2011:Q3 in conjunction with the US debt-ceiling crisis, and Bernanke's speech on tapering in 2013:Q2. Positive values indicate an increase in foreign investment in Switzerland, whereas negative values indicate repatriation.

Figure 2 depicts private capital inflows to Switzerland from abroad. Capital inflows are defined as the change in foreign investment in Switzerland. Positive values indicate an increase of foreign liabilities in Switzerland, whereas negative values indicate repatriation of foreign investment in Switzerland back to countries abroad. A few observations from Figure 2 are notable. Before the financial crisis, quarterly private capital inflows were substantial and volatile, fluctuating between 
-50 percent and 100 percent of quarterly GDP. During the crisis, their volatility significantly increased. Since the financial crisis, however, private capital inflows have become much smaller in magnitude and have exhibited much less volatility. Interestingly, none of the notable events considered in this paper coincide with an unusual movement in private capital inflows to Switzerland. In fact, during those quarters, inflows were fairly low, at about zero percent of quarterly GDP.

Figure 3 illustrates private capital outflows from Switzerland to other countries. Capital outflows are defined as the change in Swiss investment abroad. Positive values indicate an increase in Swiss investment abroad. Conversely, negative values indicate repatriation. A few observations from Figure 3 are notable, similar to those for Figure 2. Before the financial crisis, quarterly capital outflows from Switzerland were substantial and volatile, fluctuating between -50 percent and 100 percent of quarterly GDP. During the crisis, their volatility significantly increased. Since the financial crisis, however, private capital outflows have become much smaller in magnitude and have exhibited much lower levels of volatility. Again, none of the notable events that stirred global financial markets coincided with unusual movements in private capital outflows from Switzerland.

Figure 3: Private Capital Outflows from Switzerland (\% of GDP)

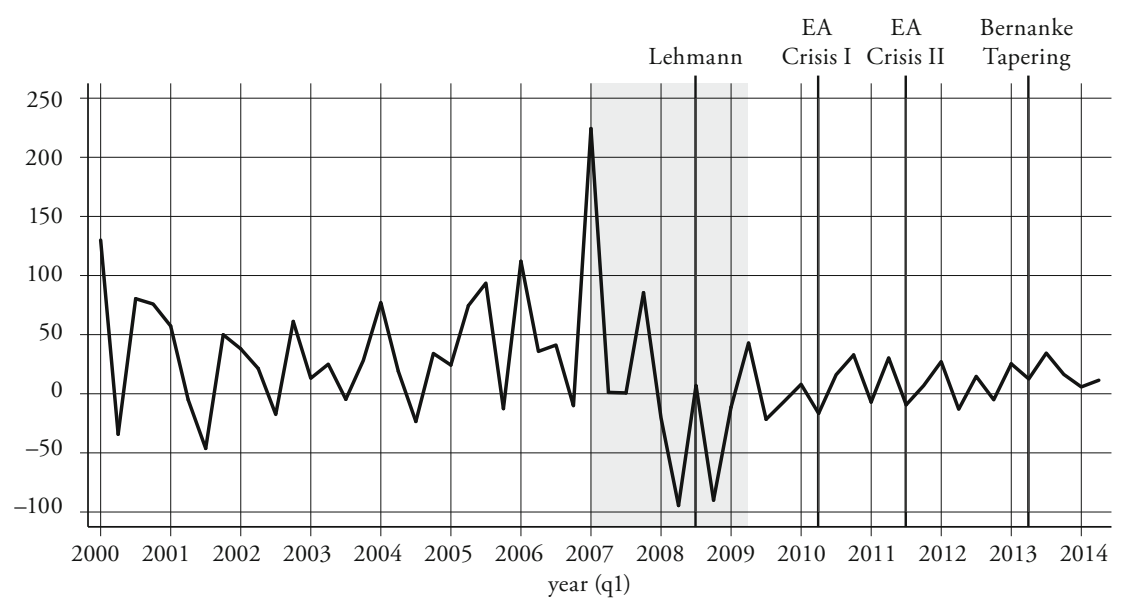

Source: SNB and author's calculations.

Note: The shaded area corresponds to the crisis period from 2007:Q1 to 2009:Q2. Four vertical lines indicate notable events during the sample period. These events are the collapse of Lehman Brothers in 2008:Q3, the bailout of Greece in 2010:Q2 amid the euro area sovereign debt crisis, the extended bailout of Greece in 2011:Q3 in conjunction with the US debt-ceiling crisis, and Bernanke's speech on tapering in 2013:Q2. Positive values indicate an increase in Swiss foreign investment abroad, whereas negative values indicate repatriation. 
On the other hand, the data for net private capital flows provide a completely different picture in Figure 4. The difference between outflows and inflows yields net capital flows. Positive values indicate net outflows from Switzerland, whereas negative values indicate net inflows to Switzerland. Because Switzerland has been running a current account surplus for the last three decades, it has had persistent net capital outflows, i.e., entities residing in Switzerland have invested more abroad than entities residing abroad have invested in Switzerland. Between 2000:Q1 and 2006:Q4, net private capital flows fluctuated between 0 percent and 30 percent of quarterly GDP. That is, although capital inflows and outflows were substantial and exhibited high volatility before the crisis (Figures 2 and 3), net capital flows were relatively smaller in magnitude and exhibited less volatility (Figure 4). However, with the onset of the crisis, both the magnitude and the volatility of net capital flows significantly increased, indicating a decoupling of capital inflows and outflows such that they no longer canceled each other out and the resulting net flows became volatile. Since 2009:Q1, net private capital flows have been fluctuating between -50 percent and 25 percent of GDP. Moreover, the volatility of net capital flows significantly increased when markets were stirred by some of the notable events considered in this paper, especially during the euro area sovereign debt crises.

Thus, the historical positive correlation between inflows to and outflows from advanced economies (BRONER et al., 2013) seems to have decreased with the financial crisis in the case of Switzerland. Figure 5 illustrates exactly this point. The figure shows the correlation coefficient between private capital inflows to and outflows from Switzerland using 12-quarter-long windows. In the beginning of the sample period, the correlation coefficient is very high close to one. Then around 2010 it starts declining sharply. In 2012:Q3, it turns slightly negative and then moves around zero until the end of the sample period. ${ }^{11}$

Based on these observations, I conjecture that the financial crisis generated a break in the investment behavior of both domestic and foreign investors. In particular, the data show that Swiss and international investors exhibit strong and long-lasting 'home bias' behavior after the financial crisis, which is consistent with the international evidence presented in Section 2.1 for financial centers.

These observations are also confirmed in Table 2, where various statistical properties of the underlying capital flows data are listed. Again, the sample period is divided into three sub-periods: the pre-crisis period, the crisis period,

11 The correlation coefficient between gross capital in- and outflows declined also notably after the financial crisis, albeit not as sharply as in the case of private capital flows. As of 2014:Q2, the coefficient was around 0.8 . 
Figure 4: Net Private Capital Flows to and from Switzerland (\% of GDP)

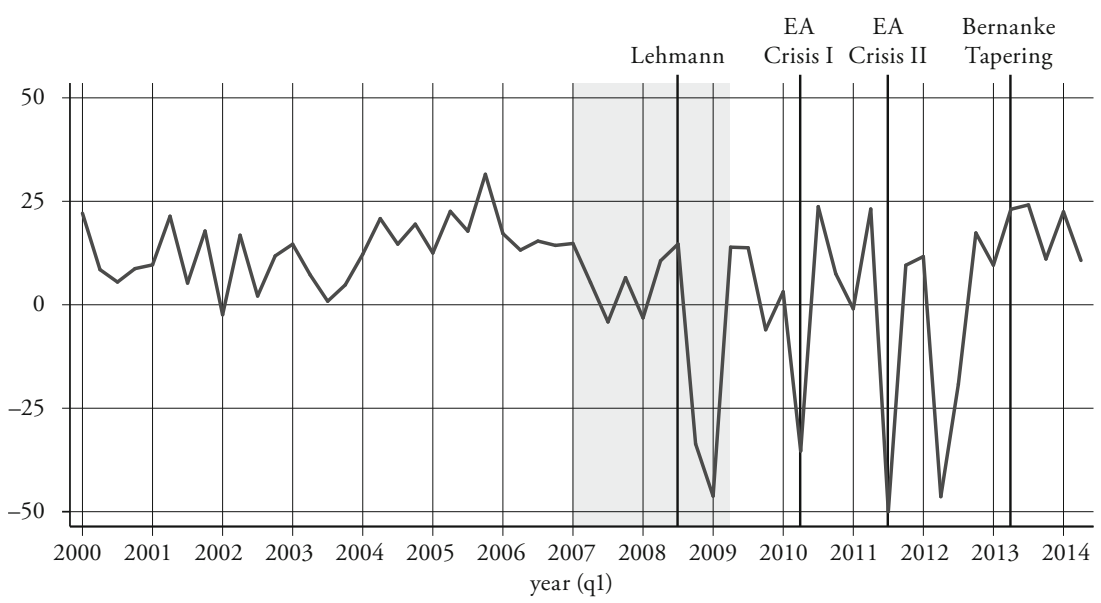

Source: SNB and author's calculations.

Note: The shaded area corresponds to the crisis period from 2007:Q1 to 2009:Q2. Four vertical lines indicate notable events during the sample period. These events are the collapse of Lehman Brothers in 2008:Q3, the bailout of Greece in 2010:Q2 amid the euro area sovereign debt crisis, the extended bailout of Greece in 2011:Q3 in conjunction the US debt-ceiling crisis, and Bernanke's speech on tapering in 2013:Q2. Positive values indicate net capital outflows from Switzerland, whereas negative values indicate net capital inflows to Switzerland.

Figure 5: Correlation between Private Capital Inflows and Outflows for Switzerland

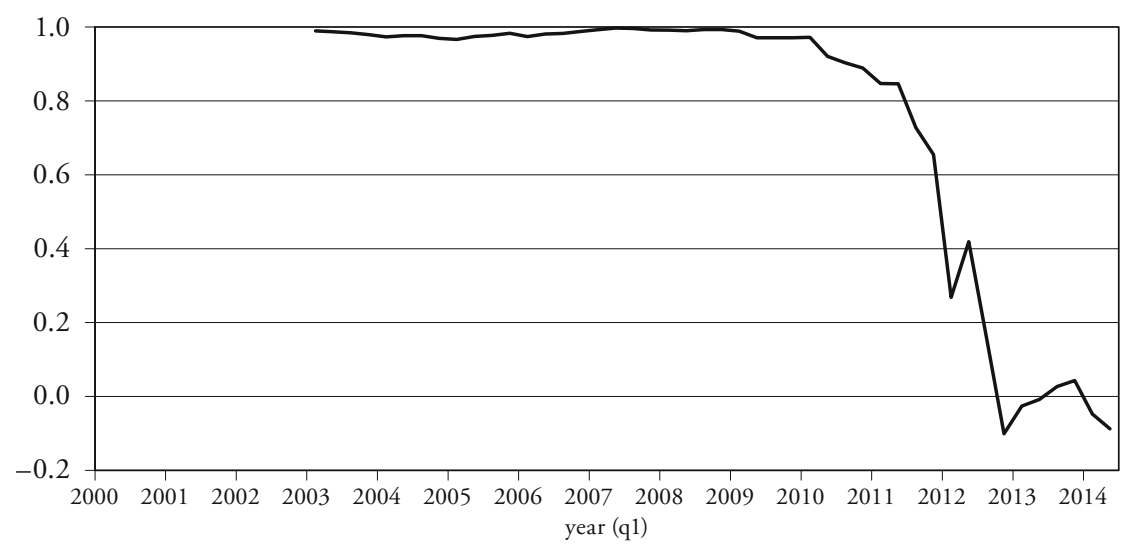

Source: SNB and author's calculations.

Note: The figure shows moving correlation coefficient between private capital inflows and outflows using 12-quarter-long rolling windows. 
and the post-crisis period. As Table 2 shows, the pre- and post-crisis sub-periods exhibit significantly different characteristics regarding the average and variance of capital flows. Specifically, both inflows and outflows of private capital have become significantly less volatile in the post-crisis period than in the pre-crisis period. By contrast, net flows have become significantly more volatile after the financial crisis than beforehand. Furthermore, both outflows and net flows have become significantly lower in the post-crisis period than in the pre-crisis period.

Table 2: Summary Statistics of Private Capital Flows from and to Switzerland (\% of GDP)

\begin{tabular}{lccc}
\hline & $\begin{array}{c}\text { Pre-crisis } \\
\text { 2000:Q1-2006:Q4 }\end{array}$ & $\begin{array}{c}\text { Crisis } \\
\text { 2007:Q1-2009:Q2 }\end{array}$ & $\begin{array}{c}\text { Post-crisis } \\
\text { 2009:Q3-2014:Q2 }\end{array}$ \\
\hline Inflows & & & \\
Min & -51.5 & -105.1 & -35.4 \\
Max & 107.9 & 209.5 & 40.7 \\
Average & 20.4 & 16.7 & 5.5 \\
Median & 20.2 & 0.3 & 5.1 \\
St Deviation & 43.5 & 84.4 & 19.5 \\
\hline Outflows & & & -21.6 \\
Min & -46.2 & -94.5 & 34.4 \\
Max & 130.0 & 224.3 & 8.1 \\
Average & 33.5 & 14.6 & 9.7 \\
Median & 31.1 & 0.9 & 17.1 \\
St Deviation & 44.3 & 91.3 & \\
\hline Net flows & & & -50.0 \\
Min & -2.4 & -46.2 & 24.1 \\
Max & 31.5 & 14.8 & 2.7 \\
Average & 13.1 & -2.1 & 10.1 \\
Median & 13.8 & 6.0 & \\
St Deviation & 7.6 & 21.2 & \\
\hline Source: SNB & & & \\
\hline & & & \\
\hline
\end{tabular}

Source: SNB and author's calculations.

Note: T-tests: There is a statistically significant difference at the $5 \%$ level between the means of the pre- and post-crisis periods for outflows and net flows.

SD-tests: There is a statistically significant difference at the $5 \%$ level between the standard deviations for the pre- and post-crisis periods for inflows, outflows, and net flows. 


\section{Capital Flow Waves: Surges, Stops, Flight, and Retrenchment}

\subsection{Methodology}

This subsection explains the methodology that is used to identify capital flow waves. Waves are defined as periods of extreme movements in capital flows relative to their behavior in the recent past. The terminology for capital waves described herein is taken from Forbes and WARNOCK (2012a) and is based on differentiating between capital flows initiated by foreign investors and those initiated by domestic investors. In other words, extreme movements in gross capital inflows and outflows are considered separately. This approach is found to yield fundamentally different results from the previous literature, which has focused on net flows only. ${ }^{12}$ The findings in Section 3.2 will be another case in point. Furthermore, as mentioned in the introduction, analyzing gross flows is more suitable for policy discussion regarding appropriate tools to alleviate the vulnerabilities of the domestic economy caused by swings in capital flows.

Following Forbes and WarNOCK (2012a), four types of extreme movements in capital flows are defined:

- A surge of gross capital inflows is a sharp increase in gross capital inflows.

- A stop of gross capital inflows is a sharp decrease in gross capital inflows.

- A flight is a sharp increase in gross capital outflows.

- A retrenchment is a sharp decrease in gross capital outflows.

In other words, foreign investors who initiate capital inflows are the drivers of surges and stops, whereas domestic investors who initiate capital outflows are the drivers of flight and retrenchment.

Previous literature has identified 'sharp' increases and decreases in capital flows by using various statistical methods, which usually involve two steps. First, smoothed levels of capital flows are calculated based on past values. Smoothed levels can be calculated, for example, by using average values based on rolling windows or by using a Hodrick-Prescott (HP) filter. Then, observations of capital flows that are significantly higher or lower than the smoothed level in each period are identified as extreme movements. Usually, the thresholds are set equal to trend plus/minus one standard deviation to identify extreme movements. ${ }^{13}$

12 See Forbes and Warnock (2012a), Broner et al. (2013), and Powell and Tavella (2012) for a discussion on gross versus net capital flows.

13 For example, Cardarelli, Elekdag, and Kose (2010) study the annual net capital inflowsto-GDP ratio by using a backward-looking rolling HP filter to smooth the data. The rolling windows are five years long. Observations that deviate from the trend by more than one 
In this paper, I use an HP filter with a recursive window to calculate the smoothed levels of capital flows. A recursive window allows for all information up to each point in time to be used to calculate the underlying trend of the data. Thus, the trend is smooth, but no historical information is lost. Furthermore, I calculate the standard deviation of capital flows by using rolling windows of 12 quarters. This window corresponds to the last three years, which is sufficiently long enough to determine the recent volatility trends and is sufficiently short to avoid having the crisis period overshadow the post-crisis period for too long. The normal range of capital flows in each quarter is then defined as the current level of the HP trend plus/minus 1.15 times the recent standard deviation. Following the previous literature, I do not consider capital flows with an absolute value of less than one percent of the GDP to be extreme movements. Using this methodology, I start by defining the 'normal range' first for 2001:Q1 based on information up to and including 2000:Q4.

For completeness of analysis, extreme movements of net capital flows are also identified in this paper. Observations of net capital flows that are significantly higher or lower than the normal range are classified as abnormally high or abnormally low values.

\subsection{Findings: Capital Flow Waves to and from Switzerland}

This subsection summarizes the findings regarding capital flow waves to and from Switzerland based on the methodology described in the previous subsection.

Figure 6 illustrates private capital inflows to Switzerland, indicating surges and stops. Between 2000:Q1 and 2006:Q4, four instances of capital surges (2004:Q1, 2005:Q2, 2005:Q3, and 2006:Q1) and one instance of a capital stop (2005:Q4) occurred. During the financial crisis, private capital inflows surged in 2007:Q1

historical standard deviation are identified as surges as long as they are economically relevant (more than one percent of GDP). Powell and Tavella (2012) follow the method suggested by Cardarelli, Elekdag, and Kose (2010) and analyze quarterly data on capital inflowsto-GDP ratios by using a HP filter and rolling windows. By contrast, Forbes and WARNOCK (2012a) study quarterly nominal capital inflows and outflows data by calculating year-overyear changes and then calculating historic averages for the last 5 years. Episodes when yearover-year changes fall above or below the historic average by more than two standard deviations are identified as capital flow wave episodes as long as they last at least two quarters. Some papers in the literature also consider cross-country averages and use a sample criterion to identify surges in a given country; see, for example, GHosh et al. (2014). Furthermore, several papers impose the restriction that surges (or stops) last at least two quarters, such as Forbes and WarNOCK (2012b). 
and stopped in 2008:Q2. After the financial crisis, however, one instance of a capital surge occurred in 2011:Q3, and one instance of a capital stop occurred in 2012:Q4. Thus, during the run-up to the financial crisis, private capital inflows often registered surges, but since 2008:Q2, they have largely been within the normal range. Among the notable events, only the EA Crisis II event in 2011:Q3 coincided with a surge in private capital inflows.

Figure 6: Private Capital Inflows to Switzerland (\% of GDP)

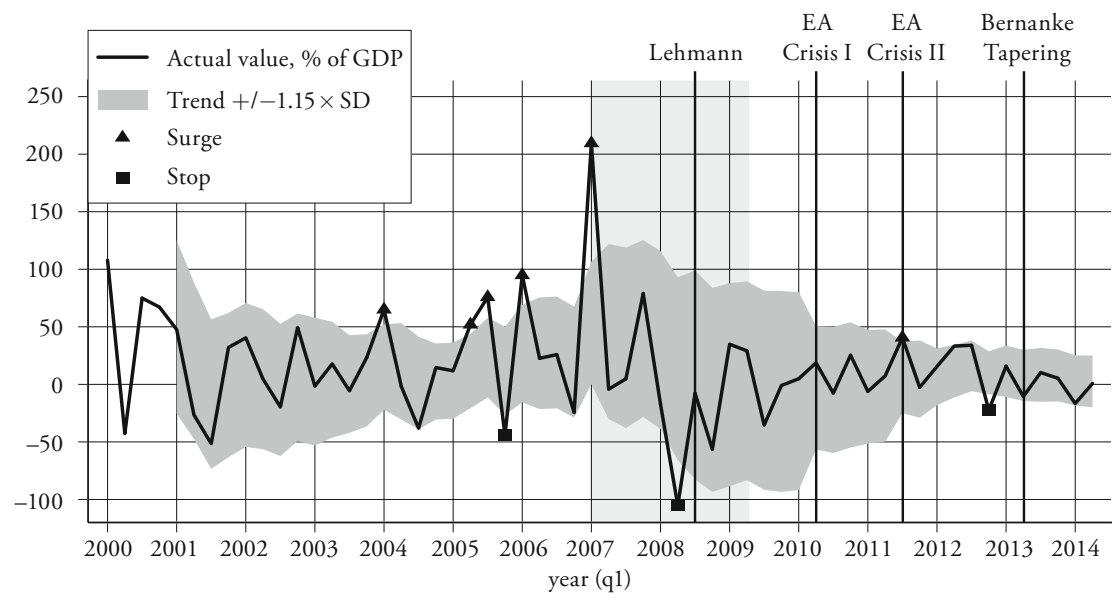

Source: SNB and author's calculations.

Note: The light-grey shaded area corresponds to the crisis period from 2007:Q1 to 2009:Q2. Four vertical lines indicate notable events during the sample period. These events are the collapse of Lehman Brothers in 2008:Q3, the bailout of Greece in 2010:Q2 amid the euro area sovereign debt crisis, the extended bailout of Greece in 2011:Q3 in conjunction the US debt-ceiling crisis, and Bernanke's speech on tapering in 2013:Q2. Surges are sharp increases in capital inflows, whereas stops are sharp decreases in inflows.

Figure 7 displays private capital outflows from Switzerland, indicating periods of flight and retrenchment. Between 2000:Q1 and 2006:Q4, four instances of capital flight (2004:Q1, 2005:Q2, 2005:Q3, and 2006:Q1) and two instances of capital retrenchment (2005:Q4 and 2006:Q4) occurred. Then, during the financial crisis, capital outflows registered a flight in 2007:Q1 and a retrenchment in 2008:Q2. Since the crisis, however, private capital outflows have shown only one extreme movement: a flight in 2013:Q3. Thus, during the run-up to the financial crisis, private capital outflows frequently registered flights, but 
since 2008:Q2, they have largely been within the normal range. None of the notable events coincided with a retrenchment or flight of capital outflows. Only the Bernanke Tapering event preceded a flight of private capital outflows from Switzerland in 2013:Q3.

Figure 7: Private Capital Outflows from Switzerland (\% of GDP)

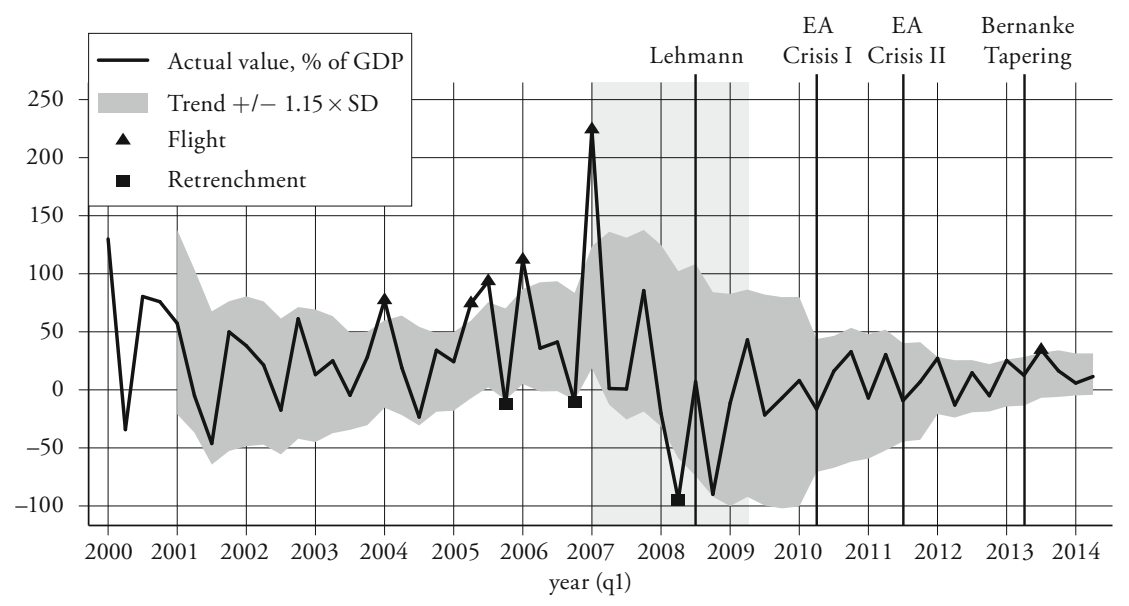

Source: SNB and author's calculations.

Note: The shaded area corresponds to the crisis period from 2007:Q1 to 2009:Q2. Four vertical lines indicate notable events during the sample period. These events are the collapse of Lehman Brothers in 2008:Q3, the bailout of Greece in 2010:Q2 amid the euro area sovereign debt crisis, the extended bailout of Greece in 2011:Q3 in conjunction the US debt-ceiling crisis, and Bernanke's speech on tapering in 2013:Q2. A flight is a sharp increase in capital inflows, whereas retrenchment is a sharp decrease in inflows.

For completeness of analysis and for purposes of comparison, extreme movements of net private capital flows are displayed in Figure 8. Between 2000:Q1 and 2014:Q2, numerous abnormal values of net private capital flows are observed. In particular, six instances of abnormally high values of net private flows and nine instances of abnormally low values of net private capital flows occurred. Interestingly, most of the abnormally high values occurred before the financial crisis, whereas most of the abnormally low values occurred during or after the financial crisis. Remarkably, two of the notable events, namely, the EA Crisis I and EA Crisis II events, coincided with abnormally low values of net private flows. Furthermore, immediately after the collapse of Lehman Brothers two abnormally low values of net private capital flows were registered in 2008:Q4 and 2009:Q1. 
Table 3 provides an overview of the extreme movements of capital flows identified in Figures 6 to 8. It has two main purposes. First, it shows any (de)synchronization of extreme movements of gross capital inflows and outflows. Second, it visually displays whether extreme movements in gross flows were responsible for the abnormal values of net flows.

Table 3 presents a number of notable characteristics of the crisis and postcrisis periods. First, at the beginning of the crisis period, extreme movements in private capital inflows and outflows were in opposite directions, counterbalancing each other to some extent. In particular, when a surge of capital inflows occurred, a flight of capital outflows occurred simultaneously, generally resulting in no abnormal values of net flows. After the crisis, however, this synchronization and counterbalancing between inflows and outflows disappeared. Second, during the crisis and post-crisis periods, frequent abnormal values of net private flows were observed, but almost none of them coincided with any surges, stops, flights, or retrenchments of capital inflows and outflows. The only exception is 2011:Q3, when a surge of private capital inflows is the driver of the abnormally low value of net private capital flows. Therefore, a greater congruence between the investment decisions of domestic and foreign investors seems to be driving the abnormal values of net flows during the post-crisis period.

The next step is to analyze the major (sub)components of capital flows. In particular, the following components and subcomponents are analyzed: direct investment, and its subcomponents equity capital, reinvested earnings, and debt instrument flows; portfolio investment, and its subcomponents debt securities and equity securities; other investment, and its subcomponents bank lending and other sectors lending; reserve assets, and its subcomponent foreign currency investment; and derivatives. Table B1 in Appendix B provides the definitions for these (sub)components, whereas Figures B1 to B14 illustrate the capital waves identified in the inflows, outflows, and net flows of each of these (sub)components. Tables 4 and 5 then summarize the findings regarding the (de)synchronization of these capital waves.

Table 4 lists the surges and stops of major components of capital inflows to Switzerland between 2000:Q1 and 2014:Q2. First, both surges and stops occurred in all of the components in at least one quarter during the sample period. Frequently, stops were immediately followed by surges in the following quarter, or vice versa. For example, the surge in bank lending inflows in 2007:Q1 was followed by a stop in 2007:Q2. However, there are also periods in which a stretch of stops or surges can be identified in the data. For example, inflows of debt securities surged starting in 2010:Q2 for three consecutive quarters and then stopped in 2011:Q3 for two consecutive quarters. By contrast, capital flow waves 
were generally short lived. Furthermore, different components of capital inflows often exhibited extreme movements in the opposite direction. For example, in 2011:Q3, while debt instruments (a subcomponent of direct investment) and debt securities (a subcomponent of portfolio investment) experienced stops in capital inflows, bank lending (a subcomponent of other investment) registered a surge of capital inflows. These results may reflect substitution behavior between different types of investment by foreign investors. Interestingly, surges (or stops) in gross capital inflows coincide with surges (or stops) in bank lending inflows to a large extent: Gross capital inflows registered an extreme movement in ten quarters during the sample period, where eight cases were coincident with an extreme movement in bank lending inflows. Waves in the remaining (sub)components of capital outflows cannot be matched with waves in gross capital inflows, likely because these components constitute a relatively small share of gross capital flows.

Figure 8: Net Private Capital Flows to and from Switzerland (\% of GDP)

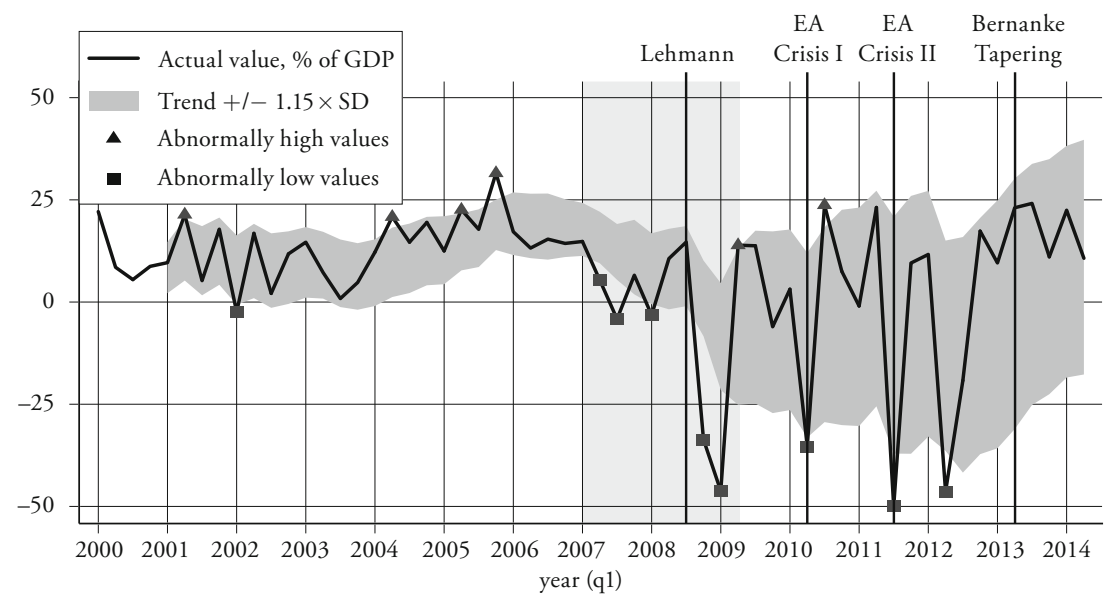

Source: SNB and author's calculations.

Note: The shaded area corresponds to the crisis period from 2007:Q1 to 2009:Q2. Four vertical lines indicate notable events during the sample period. These events are the collapse of Lehman Brothers in 2008:Q3, the bailout of Greece in 2010:Q2 amid the euro area sovereign debt crisis, the extended bailout of Greece in 2011:Q3 in conjunction the US debt-ceiling crisis, and Bernanke's speech on tapering in 2013:Q2.

Table 5, by contrast, records the periods of flight and retrenchment in major components of capital outflows from Switzerland between 2000:Q1 and 2014:Q2. As 
with the components of capital inflows, extreme movements in both directions occurred in almost all components of capital outflows during the sample period. Frequently, a period of capital flight was followed by a period of retrenchment, or vice versa. For example, a flight of capital outflow in bank lending in 2007:Q1 was followed by a retrenchment in 2007:Q2. Further, sometimes several types of capital flows registered a flight or retrenchment simultaneously. For example, in 2004:Q1, six (sub)components of capital outflows of 12 (sub)components considered registered a flight. However, at other times, different types of capital flows exhibited waves in opposite directions. For example, in 2006:Q3, portfolio investment registered a retrenchment, whereas direct investment registered a flight. As with capital inflows, capital flow waves in gross capital outflows coincide with capital flow waves in bank lending outflows to a large extent: Gross capital outflows registered an extreme movement in eleven quarters during the sample period, where eight cases were coincident with an extreme movement in bank lending outflows. Waves in the remaining components of capital outflows cannot be matched with waves in gross capital outflows.

In summary, many components of capital flows displayed waves in inflows and outflows during the crisis period. Since the financial crisis, capital flows have continued to exhibit waves in some components, such as equity capital and debt securities; however, these waves are not coincident with capital flow waves in gross flows. Waves in bank lending flows, by contrast, coincide with waves in gross flows. Furthermore, although capital flow waves are sometimes synchronized in several components, these periods of synchronization are often short lived and are succeeded by waves in the opposite direction. 
Table 3: Capital Flow Waves

\begin{tabular}{|c|c|c|c|c|}
\hline & Private inflows & Private outflows & Net private flows & Notable events \\
\hline \multicolumn{5}{|c|}{ Pre-crisis period } \\
\hline \multicolumn{5}{|l|}{ 2000:Q1 } \\
\hline \multicolumn{5}{|l|}{ 2000:Q2 } \\
\hline \multicolumn{5}{|l|}{ 2000:Q3 } \\
\hline \multicolumn{5}{|l|}{ 2000:Q4 } \\
\hline \multicolumn{5}{|l|}{ 2001:Q1 } \\
\hline 2001:Q2 & & & Abnorm. high & \\
\hline \multicolumn{5}{|l|}{ 2001:Q3 } \\
\hline \multicolumn{5}{|l|}{ 2001:Q4 } \\
\hline \multicolumn{5}{|c|}{ Abnorm. low } \\
\hline \multicolumn{5}{|l|}{$\ldots$} \\
\hline 2004:Q1 & Surge & Flight & & \\
\hline 2004:Q2 & & & Abnorm. high & \\
\hline \multicolumn{5}{|l|}{ 2004:Q3 } \\
\hline \multicolumn{5}{|l|}{ 2004:Q4 } \\
\hline \multicolumn{5}{|l|}{ 2005:Q1 } \\
\hline 2005:Q2 & Surge & Flight & Abnorm. high & \\
\hline 2005:Q3 & Surge & Flight & & \\
\hline 2005:Q4 & Stop & Retrenchment & Abnorm. high & \\
\hline 2006:Q1 & Surge & Flight & & \\
\hline \multicolumn{5}{|l|}{ 2006:Q2 } \\
\hline \multicolumn{5}{|l|}{ 2006:Q3 } \\
\hline 2006:Q4 & & Retrenchment & & \\
\hline \multicolumn{5}{|c|}{ Crisis period } \\
\hline 2007:Q1 & Surge & Flight & & \\
\hline 2007:Q2 & & & Abnorm. low & \\
\hline 2007:Q3 & & & Abnorm. low & \\
\hline \multicolumn{5}{|l|}{ 2007:Q4 } \\
\hline 2008:Q1 & & & Abnorm. low & \\
\hline 2008:Q2 & Stop & Retrenchment & & \\
\hline 2008:Q3 & & & & Lehman Collapse \\
\hline 2008:Q4 & & & Abnorm. low & \\
\hline 2009:Q1 & & & Abnorm. low & \\
\hline 2009:Q2 & & & Abnorm. high & \\
\hline \multicolumn{5}{|c|}{ Post-crisis period } \\
\hline \multicolumn{5}{|l|}{ 2009:Q3 } \\
\hline 2009:Q4 & & & & \\
\hline
\end{tabular}




\begin{tabular}{|c|c|c|c|c|}
\hline & Private inflows & Private outflows & Net private flows & Notable events \\
\hline \multicolumn{5}{|l|}{ 2010:Q1 } \\
\hline 2010:Q2 & & & Abnorm. low & Euro area crisis I \\
\hline 2010:Q3 & & & Abnorm. high & \\
\hline \multicolumn{5}{|l|}{ 2010:Q4 } \\
\hline \multicolumn{5}{|l|}{ 2011:Q1 } \\
\hline \multicolumn{5}{|l|}{ 2011:Q2 } \\
\hline 2011:Q3 & Surge & & Abnorm. low & Euro area crisis II \\
\hline \multicolumn{5}{|l|}{ 2011:Q4 } \\
\hline \multicolumn{5}{|l|}{ 2012:Q1 } \\
\hline 2012:Q2 & & & Abnorm. low & \\
\hline \multicolumn{5}{|l|}{ 2012:Q3 } \\
\hline 2012:Q4 & Stop & & & \\
\hline \multicolumn{5}{|l|}{ 2013:Q1 } \\
\hline 2013:Q2 & & & & Bernanke tapering \\
\hline 2013:Q3 & & Flight & & \\
\hline \multicolumn{5}{|l|}{ 2013:Q4 } \\
\hline \multicolumn{5}{|l|}{ 2014:Q1 } \\
\hline 2014:Q2 & & & & \\
\hline
\end{tabular}

Source: SNB and author's calculations.

Note: The highlighted dates correspond in this order to: the collapse of Lehman Brothers in 2008:Q3, the bailout of Greece in 2010:Q2 amid the euro area sovereign debt crisis, the extended bailout of Greece in 2011:Q3 along with the US debt ceiling crisis, and Bernanke's speech on tapering in 2013:Q2.

Table 4: Surges and Stops of Capital Inflows to Switzerland

\begin{tabular}{|c|c|c|c|c|c|c|c|c|c|c|c|}
\hline 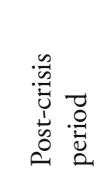 & 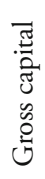 & 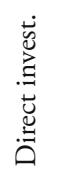 & 总营 & 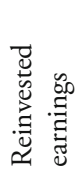 & 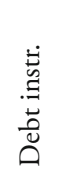 & 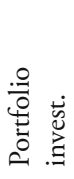 & 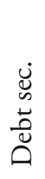 & 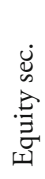 & 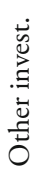 & 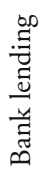 & 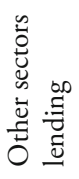 \\
\hline \multicolumn{12}{|c|}{ Pre-crisis period } \\
\hline \multicolumn{12}{|l|}{ 2000:Q1 } \\
\hline \multicolumn{12}{|l|}{ 2000:Q2 } \\
\hline \multicolumn{12}{|l|}{ 2000:Q3 } \\
\hline \multicolumn{12}{|l|}{ 2000:Q4 } \\
\hline 2001:Q1 & & Stop & & Stop & Stop & & & & & & Surge \\
\hline 2001:Q2 & & & & & & & & & & & Stop \\
\hline
\end{tabular}




\begin{tabular}{|c|c|c|c|c|c|c|c|c|c|c|c|}
\hline 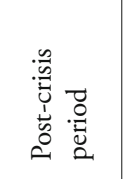 & 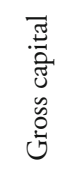 & 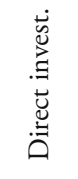 & 氖胥泀 & 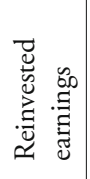 & 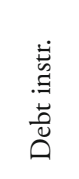 & 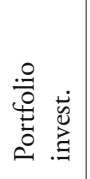 & 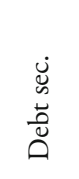 & 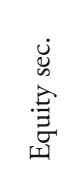 & 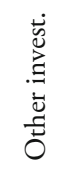 & 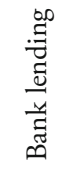 & 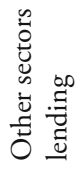 \\
\hline 2001:Q3 & & & & & & & & & & & \\
\hline 2001:Q4 & & & & & & & & & & & \\
\hline 2002:Q1 & & & & & & & & & & & \\
\hline 2002:Q2 & & & & & & & & & & & \\
\hline 2002:Q3 & & & & & & & & & & & \\
\hline 2002:Q4 & & & & & & & Surge & & & & Surge \\
\hline 2003:Q1 & & & & & & Stop & & Stop & & & Surge \\
\hline 2003:Q2 & & & & & & & & & & & \\
\hline 2003:Q3 & & Surge & & Surge & Surge & & & & & & \\
\hline 2003:Q4 & & & Surge & & Stop & & Surge & & & & \\
\hline 2004:Q1 & Surge & & & & & & & & Surge & Surge & \\
\hline 2004:Q2 & & & & & & & Surge & & & & \\
\hline 2004:Q3 & Stop & & Stop & Surge & & & & & Stop & Stop & \\
\hline 2004:Q4 & & & & Surge & & & & & & & Stop \\
\hline 2005:Q1 & & Stop & & Stop & & & & & & & Surge \\
\hline 2005:Q2 & Surge & & & Surge & & & & Surge & Surge & Surge & \\
\hline 2005:Q3 & Surge & Surge & & Surge & & & & & Surge & Surge & \\
\hline 2005:Q4 & Stop & Stop & & Stop & Stop & & & & Stop & Stop & \\
\hline 2006:Q1 & Surge & Surge & Surge & & & & Stop & & Surge & Surge & \\
\hline 2006:Q2 & & Surge & & & & & & & & & \\
\hline 2006:Q3 & & & & & & & & & & & Surge \\
\hline 2006:Q4 & & Surge & Surge & & & Surge & Surge & & Stop & Stop & Stop \\
\hline \multicolumn{12}{|c|}{ Crisis period } \\
\hline 2007:Q1 & Surge & & & & & & & Stop & Surge & Surge & Surge \\
\hline 2007:Q2 & & & & Surge & & & Stop & Surge & & Stop & Surge \\
\hline 2007:Q3 & & & & & & Stop & & Stop & & & \\
\hline 2007:Q4 & & & & & Stop & Surge & & Surge & & & Stop \\
\hline 2008:Q1 & & & & Stop & & Surge & & Surge & & & Surge \\
\hline 2008:Q2 & Stop & & & & Surge & & & & Stop & Stop & \\
\hline
\end{tabular}




\begin{tabular}{|c|c|c|c|c|c|c|c|c|c|c|c|}
\hline 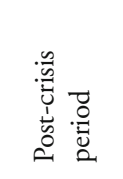 & 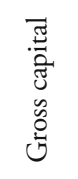 & 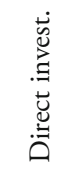 & 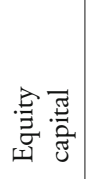 & 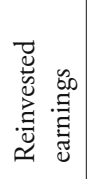 & 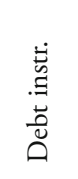 & 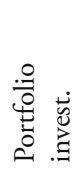 & $\begin{array}{l}\dot{u} \\
\dot{u} \\
\tilde{0} \\
0\end{array}$ & 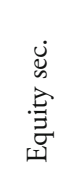 & 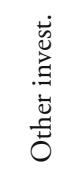 & 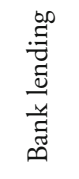 & 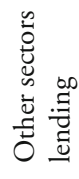 \\
\hline 2008:Q3 & & Stop & & Stop & Stop & & & & & & Stop \\
\hline $\begin{array}{l}\text { 2008:Q4 } \\
\text { 2009:Q1 } \\
\text { 2009:Q2 }\end{array}$ & & & & & & $\begin{array}{l}\text { Surge } \\
\text { Surge }\end{array}$ & Surge & Surge & & & Stop \\
\hline \multicolumn{12}{|c|}{ Post-crisis period } \\
\hline $\begin{array}{l}\text { 2009:Q3 } \\
\text { 2009:Q4 } \\
\text { 2010:Q1 }\end{array}$ & & & & & & $\begin{array}{l}\text { Stop } \\
\text { Stop }\end{array}$ & Stop & $\begin{array}{l}\text { Stop } \\
\text { Stop }\end{array}$ & & & \\
\hline 2010:Q2 & & & & & & Surge & Surge & & & & \\
\hline $\begin{array}{l}\text { 2010:Q3 } \\
\text { 2010:Q4 } \\
\text { 2011:Q1 } \\
\text { 2011:Q2 }\end{array}$ & & & Stop & & $\begin{array}{l}\text { Surge } \\
\text { Surge }\end{array}$ & Surge & $\begin{array}{l}\text { Surge } \\
\text { Surge }\end{array}$ & Stop & & & \\
\hline 2011:Q3 & & & & & Stop & Stop & Stop & & Surge & Surge & \\
\hline $\begin{array}{l}\text { 2011:Q4 } \\
\text { 2012:Q1 } \\
\text { 2012:Q2 } \\
\text { 2012:Q3 } \\
\text { 2012:Q4 } \\
\text { 2013:Q1 }\end{array}$ & Surge & $\begin{array}{l}\text { Stop } \\
\text { Stop }\end{array}$ & Stop & Surge & $\begin{array}{l}\text { Surge } \\
\text { Stop }\end{array}$ & & Stop & Surge & Stop & Stop & \\
\hline 2013:Q2 & & & Stop & & Surge & & & & & & \\
\hline $\begin{array}{l}\text { 2013:Q3 } \\
\text { 2013:Q4 } \\
\text { 2014:Q1 } \\
\text { 2014:Q2 }\end{array}$ & & $\begin{array}{l}\text { Surge } \\
\text { Surge }\end{array}$ & & $\begin{array}{l}\text { Surge } \\
\text { Stop } \\
\text { Surge }\end{array}$ & & & & Stop & & & \\
\hline
\end{tabular}

Source: SNB and author's calculations.

Note: The highlighted dates correspond to the collapse of Lehman Brothers in 2008:Q3, the bailout of Greece in 2010:Q2 amid the euro area sovereign debt crisis, the extended bailout of Greece in 2011:Q3 in conjunction the US debt-ceiling crisis, and Bernanke's speech on tapering in 2013:Q2. 


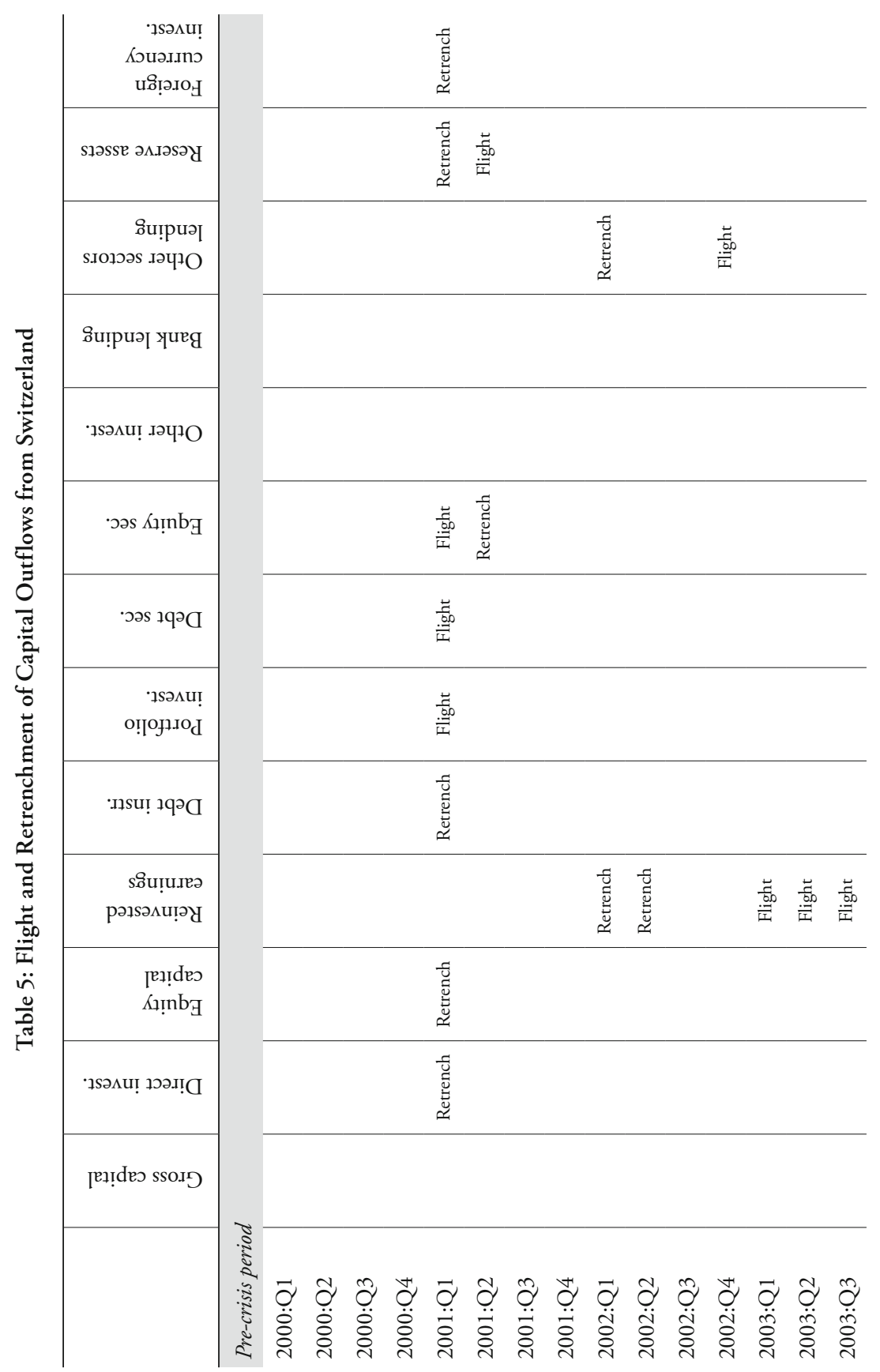




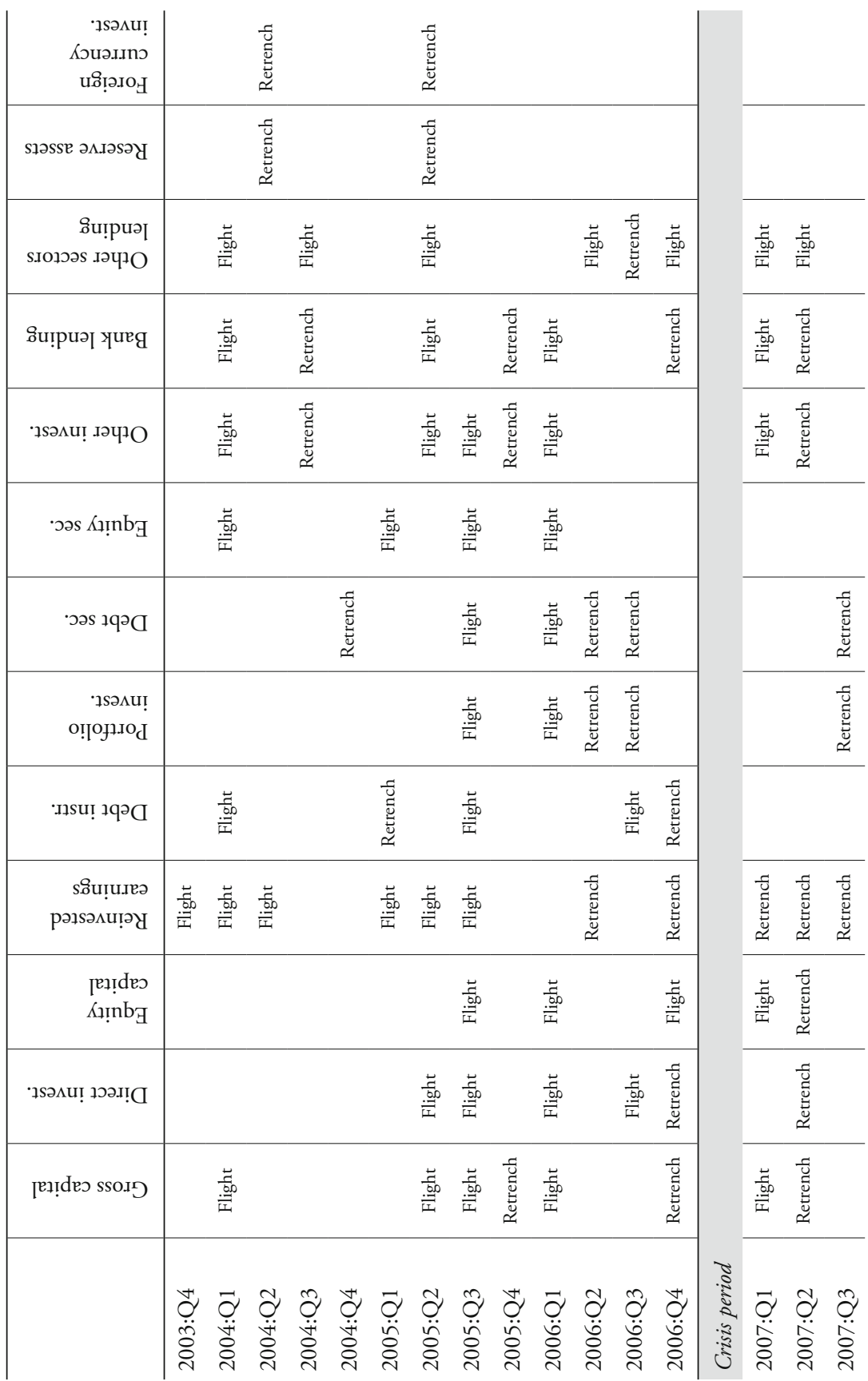




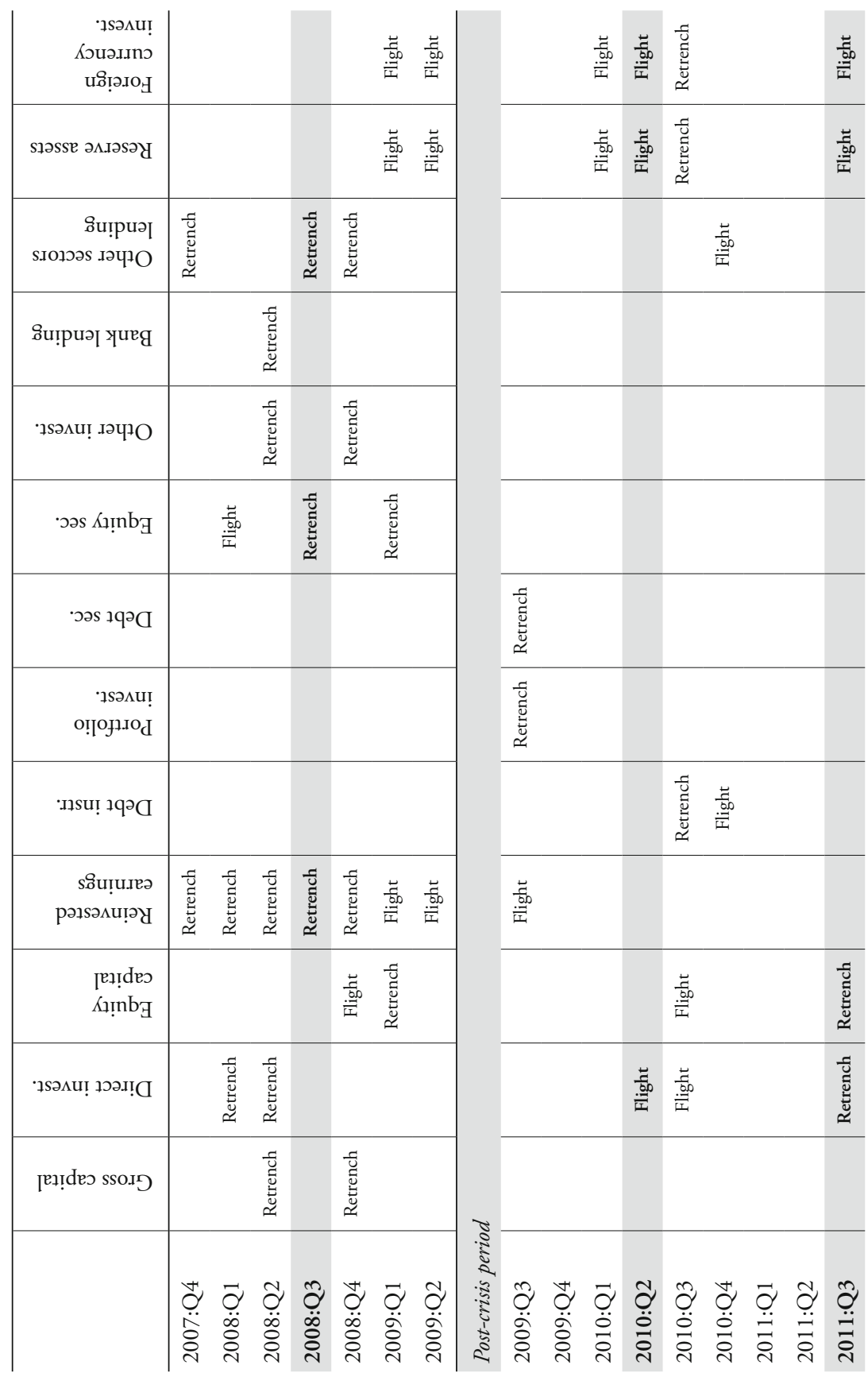




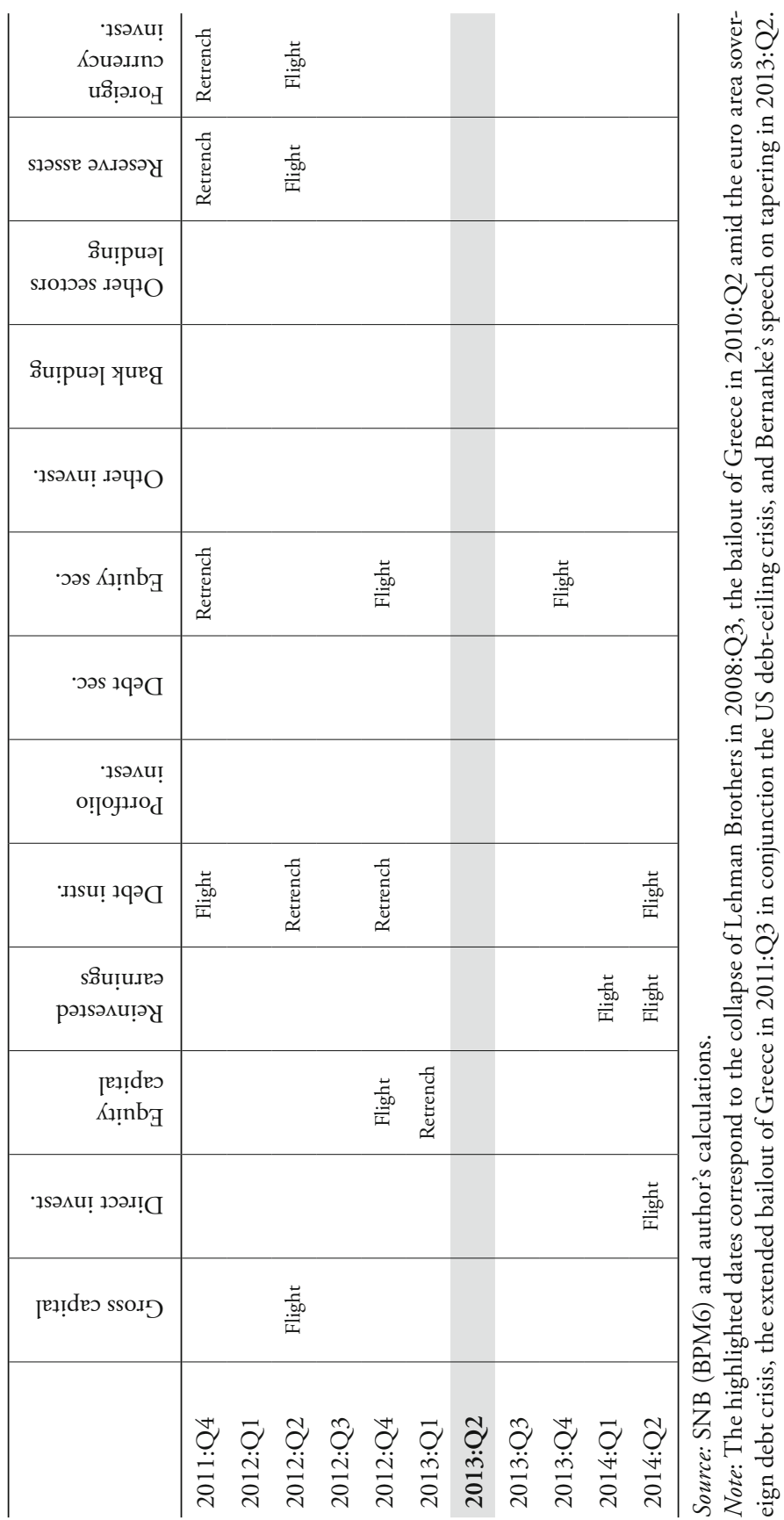




\section{Conclusion}

This paper documents the behavior of international capital flows before and after the global financial crisis with a special focus on Switzerland, a financial center with a small open economy. Data show that the global financial crisis of 20072008 had a permanent effect on investor behavior across the globe. Indeed, a long-lasting and strong home bias among investors is observed in many countries since the crisis, as investors have been undertaking significantly less new foreign investment in the post-crisis period than in the pre-crisis period. Similarly, since the financial crisis, all countries across the globe have been receiving significantly less foreign investment than before the crisis period. This phenomenon is particularly acute in financial centers as well as some advanced economies. In particular, capital inflows to and outflows from financial centers registered a disproportionately sharp drop with the onset of the crisis and did not rebound afterward.

A closer examination of the Swiss data for capital inflows and outflows reveals that since 2009:Q2, gross capital inflows to and outflows from Switzerland have been substantially lower and have exhibited significantly less volatility. By contrast, net capital flows have become much more volatile since the crisis, suggesting a decoupling of capital inflows and outflows such that they no longer cancel each other out. Thus, the historical positive correlation between inflows to and outflows from advanced economies has decreased for Switzerland with the onset of the financial crisis.

These findings are confirmed in a statistical analysis in which capital flow waves are identified. During the run-up to the financial crisis, private capital inflows often registered surges, but since 2008:Q2, they have largely been within the normal range. Similarly, during the run-up to the crisis, private capital outflows from Switzerland frequently registered flights, but since 2008:Q2, they have largely been within the normal range. By contrast, net private capital flows exhibit frequent abnormal levels, both above and below the normal range.

Furthermore, there was a high degree of synchronization of capital flow waves in different (sub)components of capital flows before and during the financial crisis. However, extreme movements of private capital flows are largely driven by extreme movements of bank lending flows. In other words, capital flow waves in bank lending are found to be the underlying cause of the extreme movements of private capital flows in general.

The analysis also shows that some of the notable events that increased the uncertainty and volatility of global financial markets were coincident with capital flow waves to and from Switzerland. In particular, two abnormally low observations of net private capital flows were coincident with the euro area sovereign 
debt crisis in 2010:Q2 and the extended bailout of Greece in conjunction the US debt-ceiling crisis in 2011:Q3. By contrast, the collapse of Lehman Brothers in 2008:Q3 and the speech by Ben Bernanke in 2013:Q2 on tapering were not coincident with extreme movements of net capital flows.

\section{Appendix A}

Figure A1: Gross Capital Inflows to Switzerland (\% of GDP)

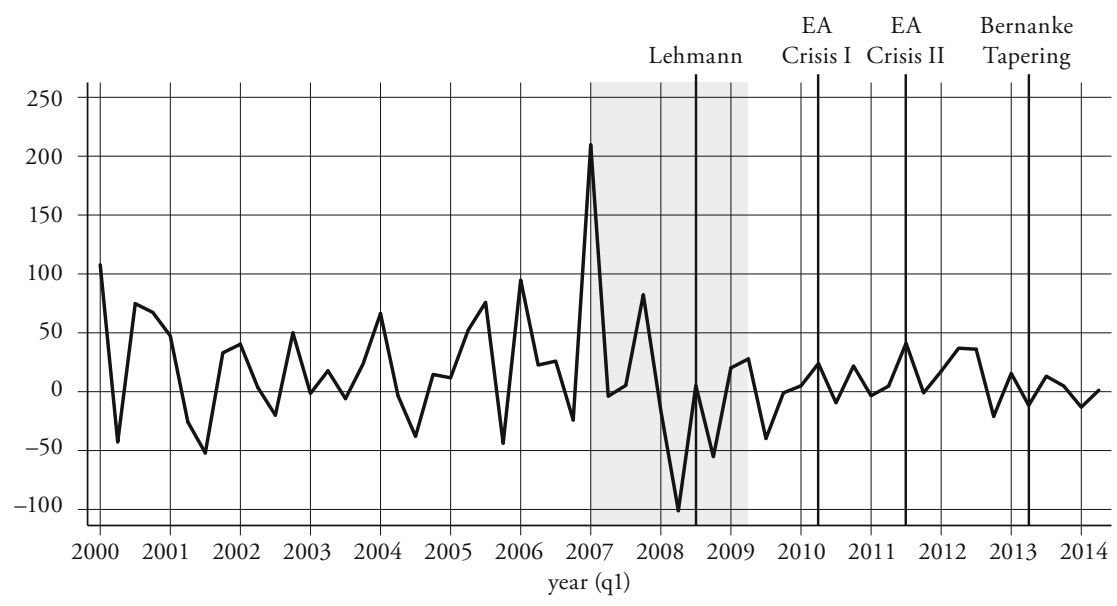

Source: SNB and author's calculations.

Note: The shaded area corresponds to the crisis period from 2007:Q1 to 2009:Q2. Four vertical lines indicate notable events during the sample period. These events are the collapse of Lehman Brothers in 2008:Q3, the bailout of Greece in 2010:Q2 amid the euro area sovereign debt crisis, the extended bailout of Greece in 2011:Q3 in conjunction the US debt-ceiling crisis, and Bernanke's speech on tapering in 2013:Q2. 
Figure A2: Gross Capital Outflows from Switzerland (\% of GDP)

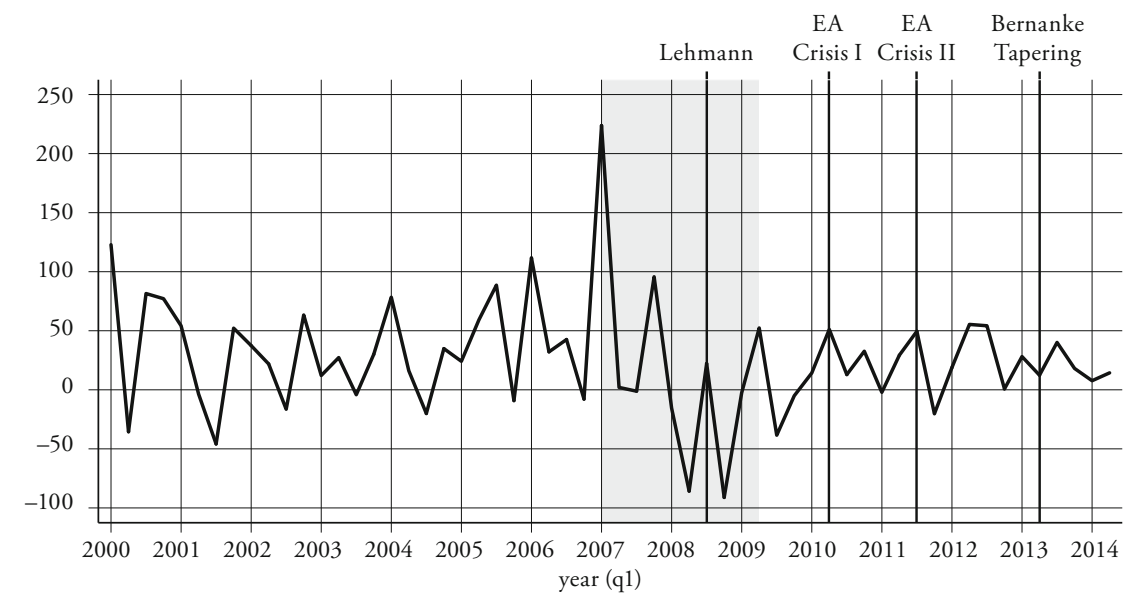

Figure A3: Net Capital Flows to and from Switzerland (\% of GDP)

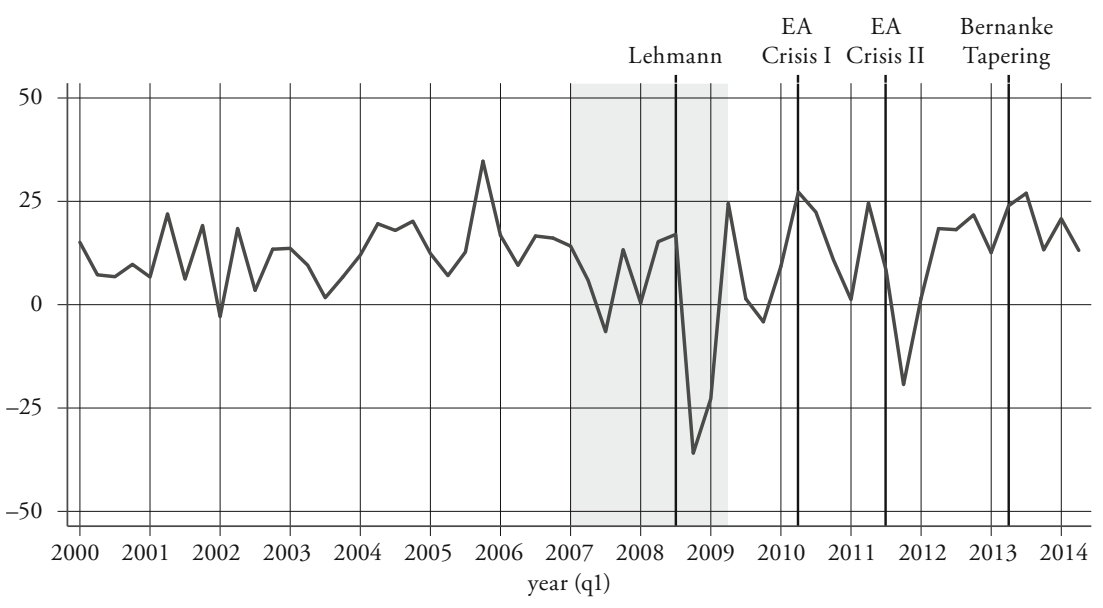

For Figures A2 and A3:

Source: SNB and author's calculations.

Note: The shaded area corresponds to the crisis period from 2007:Q1 to 2009:Q2. Four vertical lines indicate notable events during the sample period. These events are the collapse of Lehman Brothers in 2008:Q3, the bailout of Greece in 2010:Q2 amid the euro area sovereign debt crisis, the extended bailout of Greece in 2011:Q3 in conjunction the US debt-ceiling crisis, and Bernanke's speech on tapering in 2013:Q2. 


\section{Table A1: Summary Statistics of Capital Flows from and to Switzerland (\% of GDP)}

\begin{tabular}{lccc}
\hline & $\begin{array}{c}\text { Pre-crisis } \\
\text { 2000:Q1-2006:Q4 }\end{array}$ & $\begin{array}{c}\text { Crisis } \\
\text { 2007:Q1-2009:Q2 }\end{array}$ & $\begin{array}{c}\text { Post-crisis } \\
\text { 2009:Q3-2014:Q2 }\end{array}$ \\
\hline Inflows & & & \\
Min & -52.0 & -101.0 & -39.8 \\
Max & 107.8 & 209.6 & 41.2 \\
Average & 20.5 & 17.5 & 6.1 \\
Median & 20.2 & 5.3 & 4.8 \\
Std. Deviation & 43.6 & 83.3 & 20.4 \\
\hline Outflows & & & -38.4 \\
Min & -45.8 & -91.1 & 55.4 \\
Max & 122.8 & 223.8 & 18.7 \\
Average & 33.0 & 20.0 & 16.2 \\
Median & 31.1 & 0.5 & 24.9 \\
Std. Deviation & 42.8 & 90.9 & \\
\hline Net flows & & & -19.3 \\
Min & 12.6 & -35.9 & 27.2 \\
Max & -2.9 & 24.5 & 12.6 \\
Average & 34.7 & 2.5 & 13.2 \\
Median & 12.6 & 9.6 & \\
Std. Deviation & 19.2 & & \\
\hline Source: SNB & & & \\
\hline & & & \\
\hline
\end{tabular}

Source: SNB and author's calculations.

Note: T-tests: There is no statistically significant difference between the means of the pre- and post-crisis periods for inflows, outflows, and net flows. SD tests: There is a statistically significant difference at the $5 \%$ level between the standard deviations for the pre- and post-crisis periods for inflows, outflows, and net flows. 


\section{Appendix B}

\section{Table B1: Definitions of Capital Flow Variables}

\section{Private capital outflows}

Net acquisition of financial assets, excluding the central bank and the public sector

Private capital inflows

Net incurrence of financial liabilities, excluding the central bank and the public sector

Net private capital flows

Difference between private capital outflows and private capital inflows

\section{Direct investment}

Investment in which an investor owns at least 10 percent of the voting stock of a company abroad or in Switzerland, or sets up a subsidiary or branch

- Equity capital

Exceptional dividend payments, contributions to cover losses made to direct investment enterprises

- Reinvested earnings

Direct investor's share of the retained earnings or net savings of the direct investment enterprise. Can be negative in case of losses by the direct investment enterprise or if dividends payable in a period are larger than the net earnings for that period

- Debt instruments

Loans with equity character granted to direct investment enterprises

\section{Portfolio investment}

Portfolio investment abroad by Swiss residents or portfolio investment in Switzerland by foreign investors, which is not covered by direct investment

- Debt securities

Money market instruments, bonds

- Equity securities

Shares, collective investment schemes

\section{Other investment}

Residual category that includes positions and transactions other than those included in direct investment, portfolio investment, or reserve assets

- Bank lending Currency, deposits, and loans by banks. Interbank lending operations, lending to customers, mortgage claims, and precious metal claims by deposit including institutions other than central banks

\section{- Other sectors lending}

Currency, deposits, and loans by other financial corporations, non-financial corporations, households, and money market funds

\section{Reserve assets}

Change in gold holdings, foreign exchange holdings, reserve position in the IMF, and international payment instruments (SDRs)

- Foreign currency investment Change in foreign exchange holdings

\section{Derivatives}

Net payments received for derivatives; net sales of structured products

Sources: IMF: Balance of Payments Manual, Sixth Edition, http://www.elibrary.imf.org/ Swiss Balance of Payments http://www.snb.ch/en/iabout/stat/bpm6/id/stat_bpm6_uebersicht 


\section{Figure B1: Gross Capital Flows (\% of GDP)}
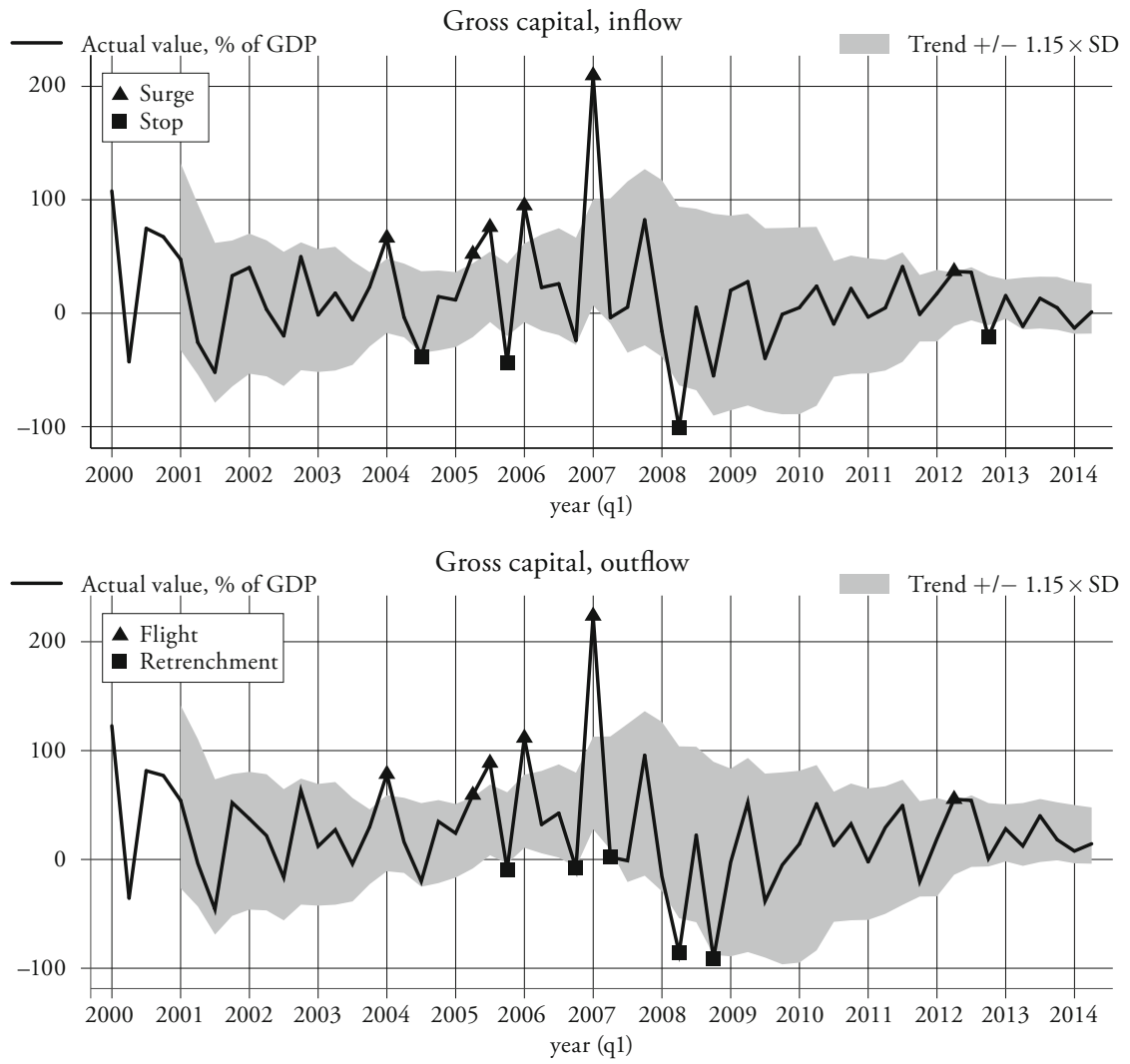

Gross capital, net

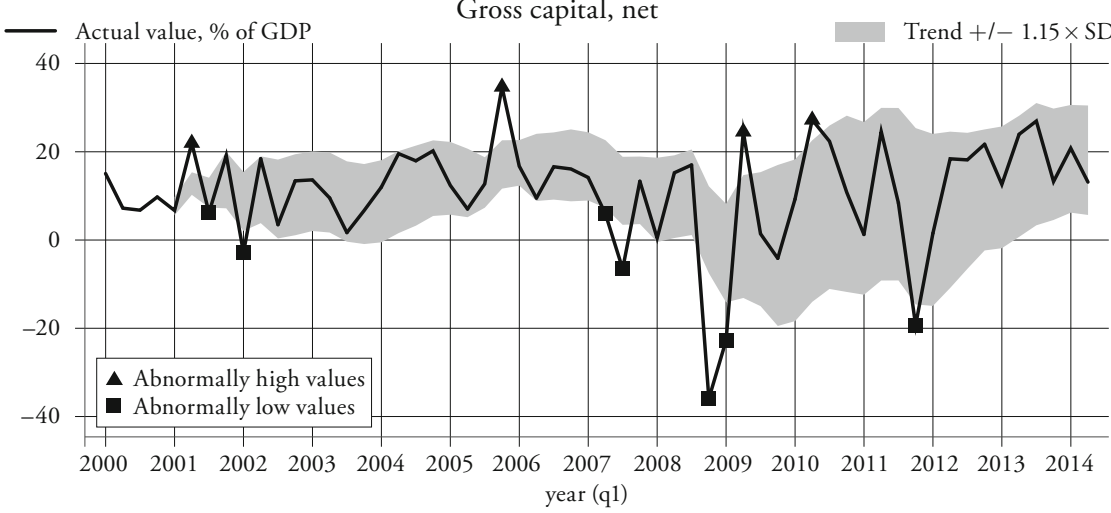

Source: SNB and author's calculations. 
Figure B2: Direct Investment Flows (\% of GDP)

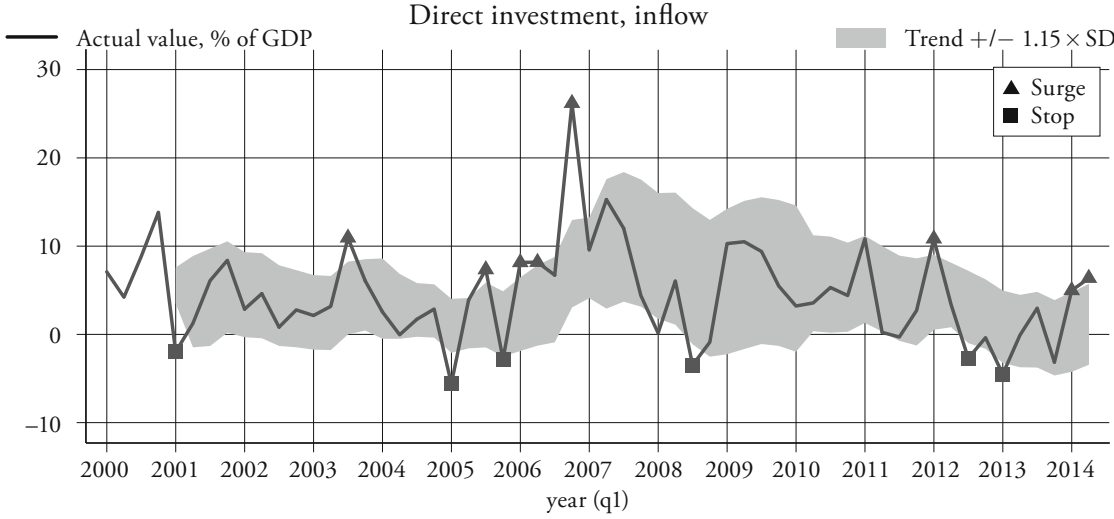

Direct investment, outflow

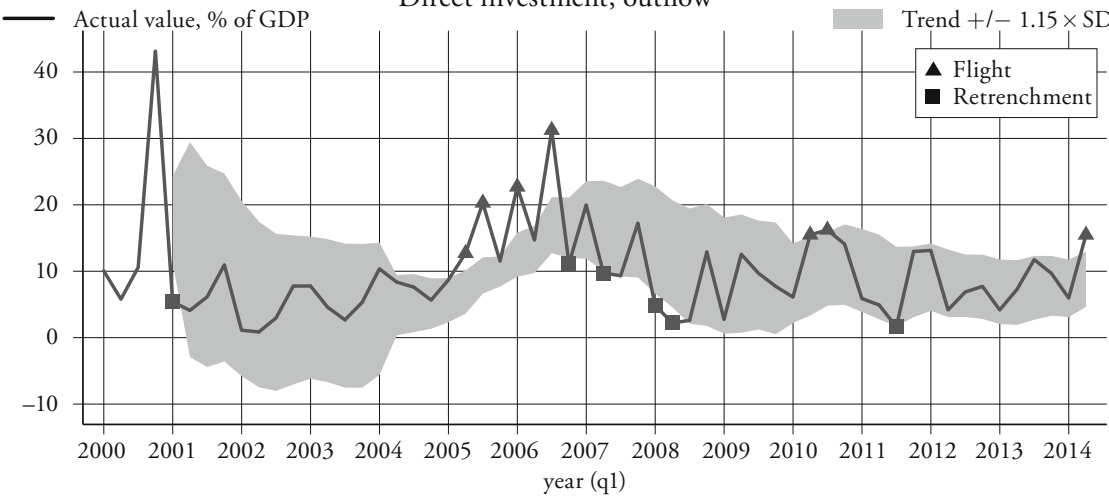

Direct investment, net

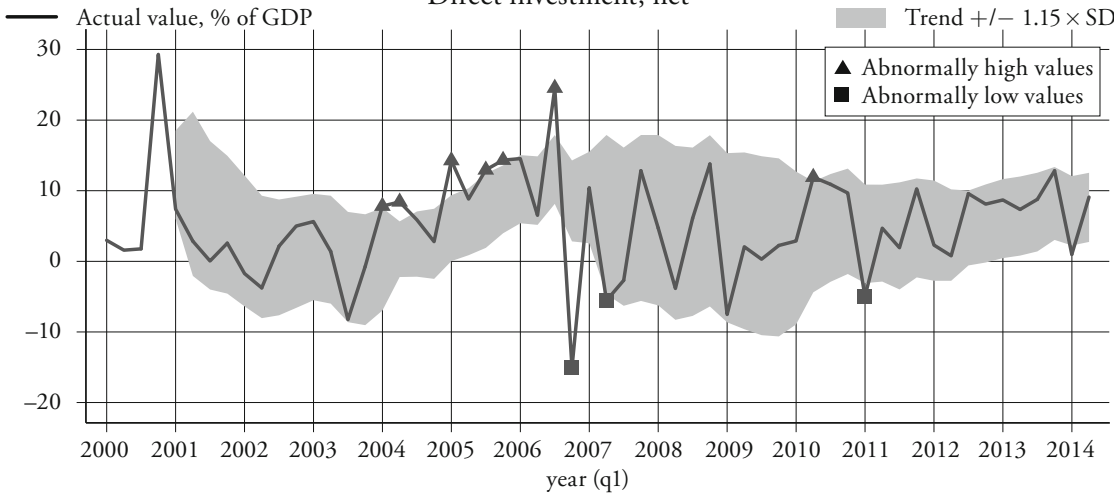

Source: SNB and author's calculations. 


\section{Figure B3: Equity Capital Flows (\% of GDP)}
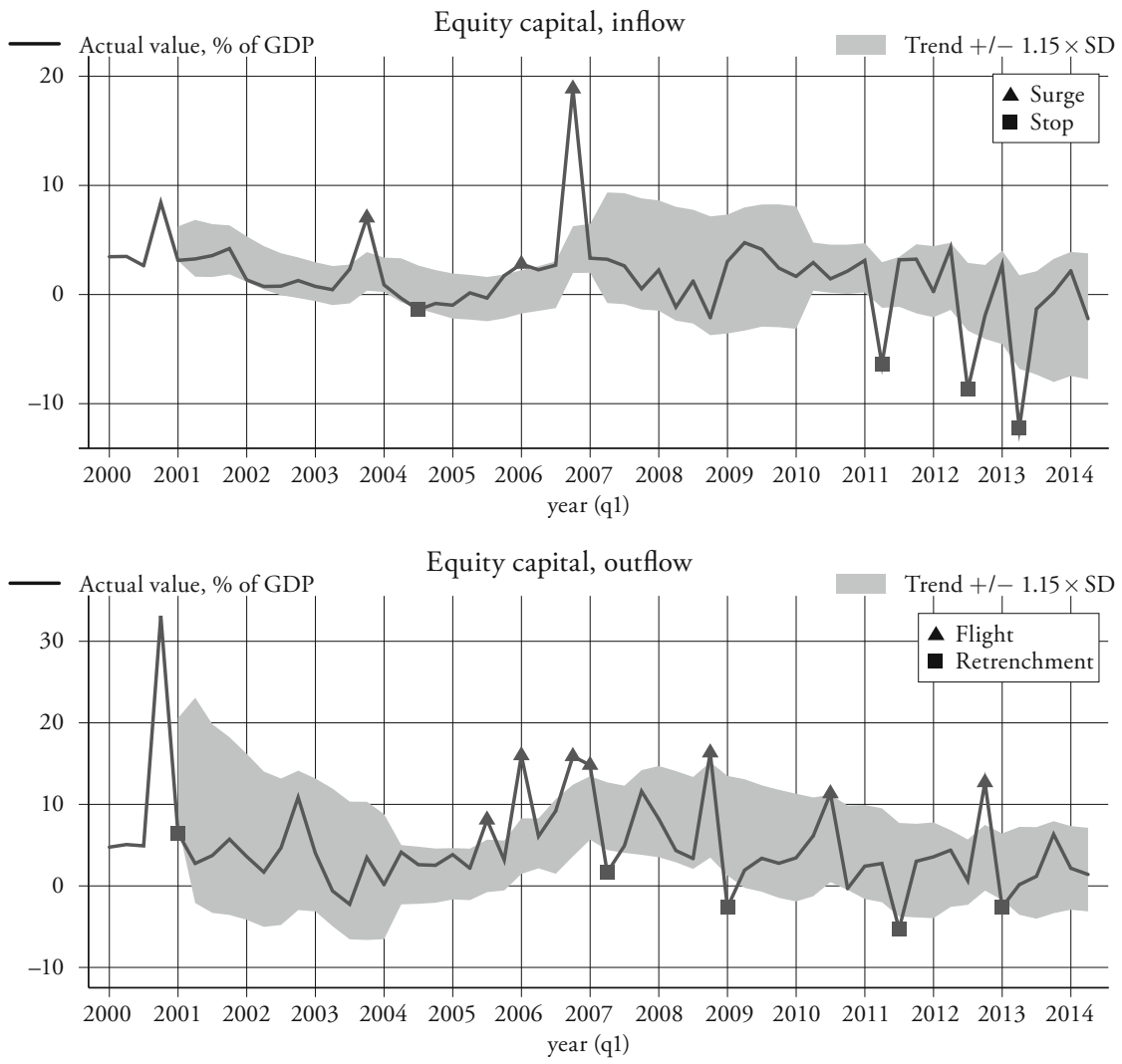

Equity capital, net

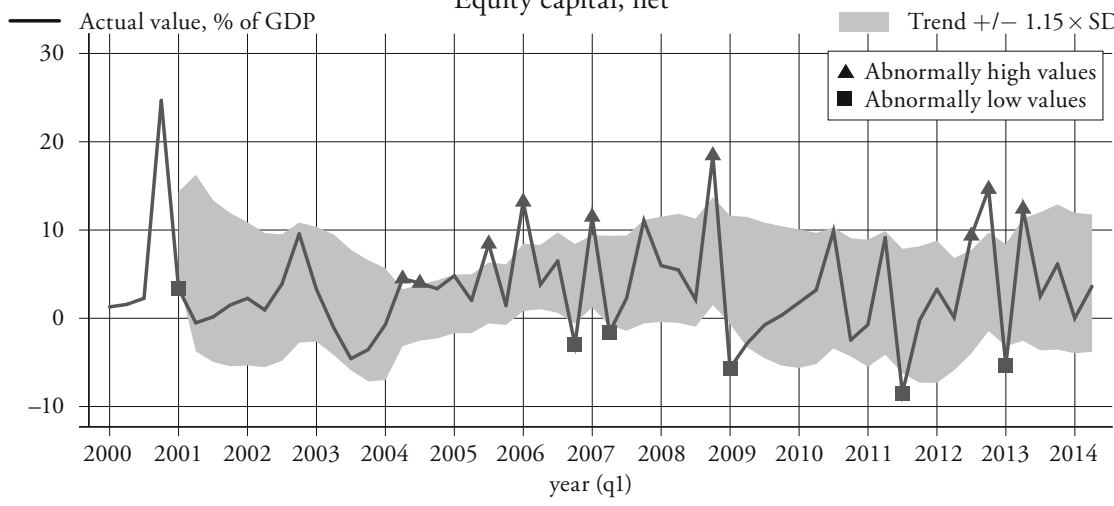

Source: SNB and author's calculations. 
Figure B4: Reinvested Earnings Flows (\% of GDP)
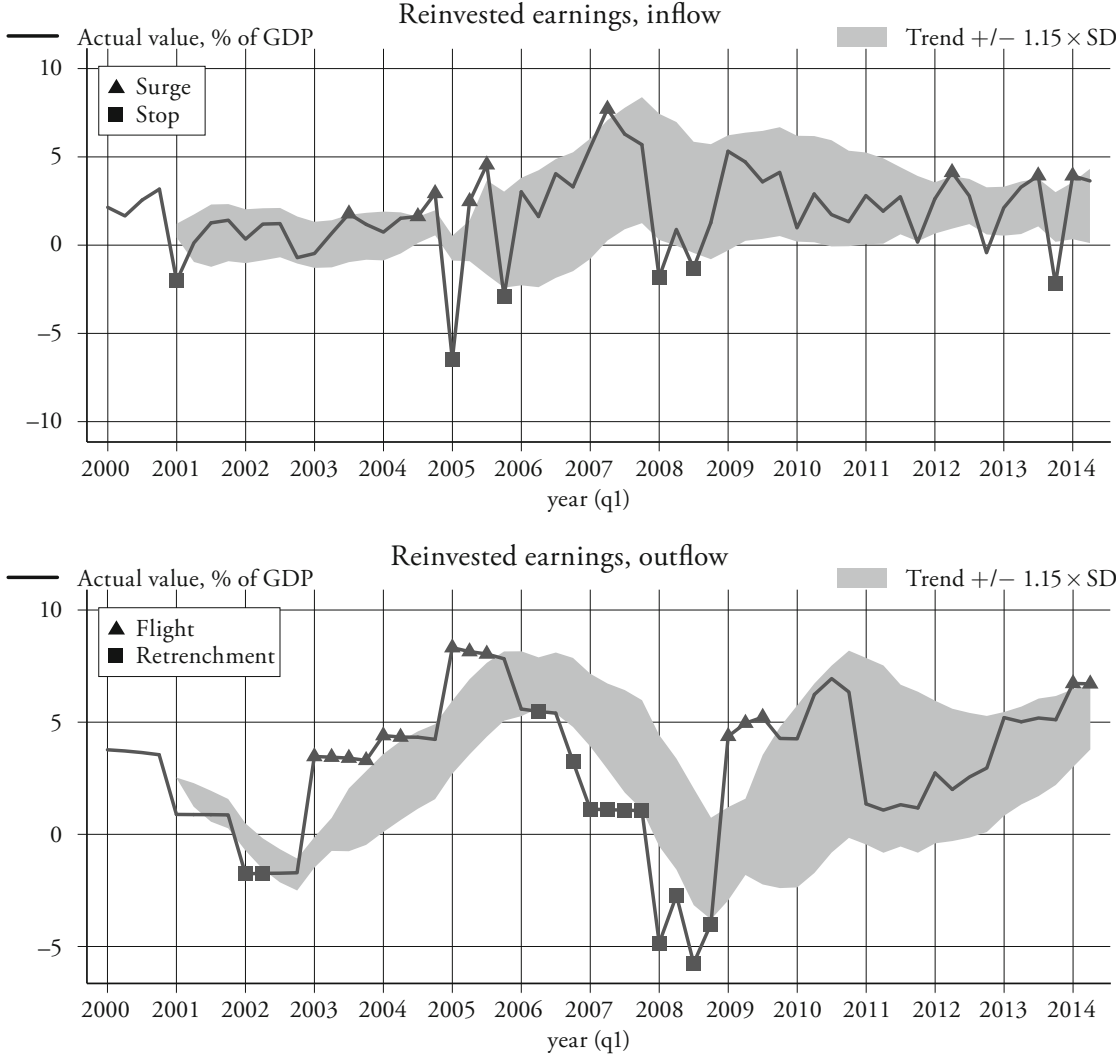

Reinvested earnings, net

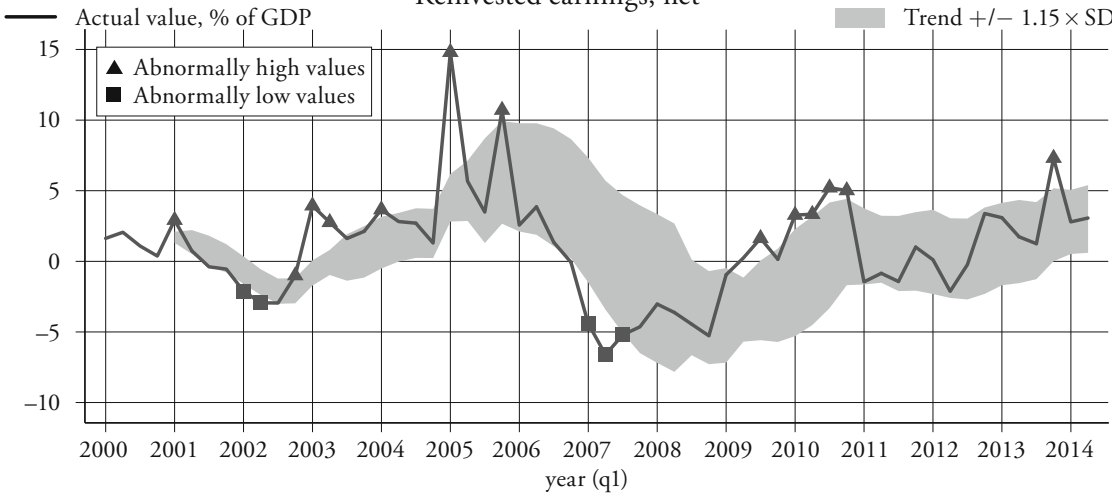

Source: SNB and author's calculations. 


\section{Figure B5: Debt Instruments Flows (\% of GDP)}

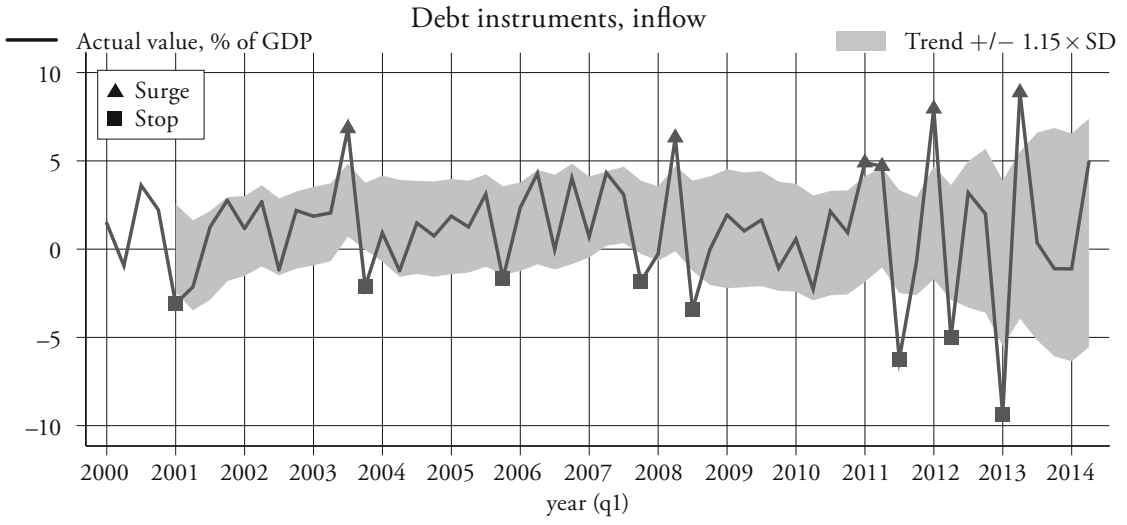

Debt instruments, outflow

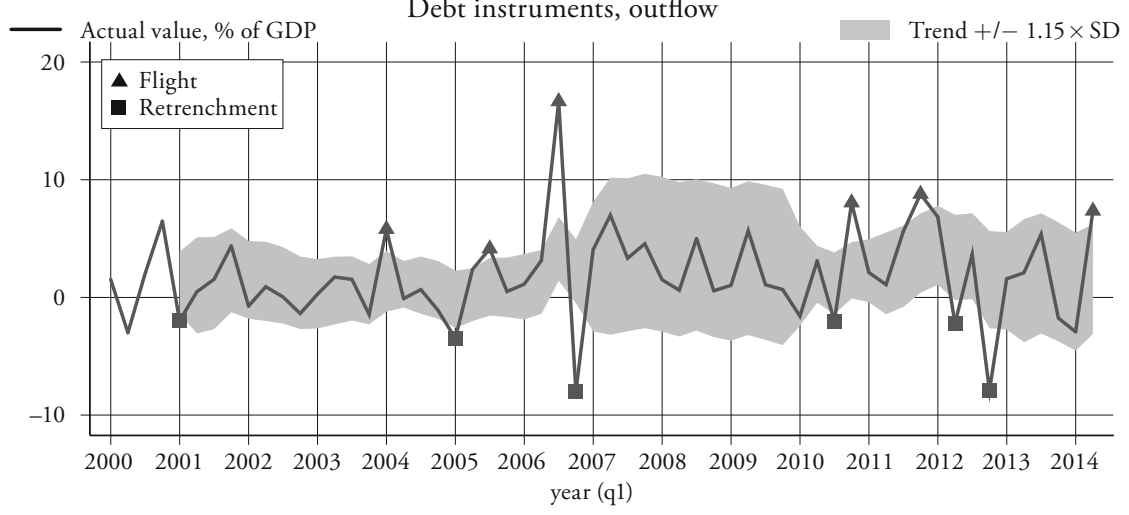

Debt instruments, net

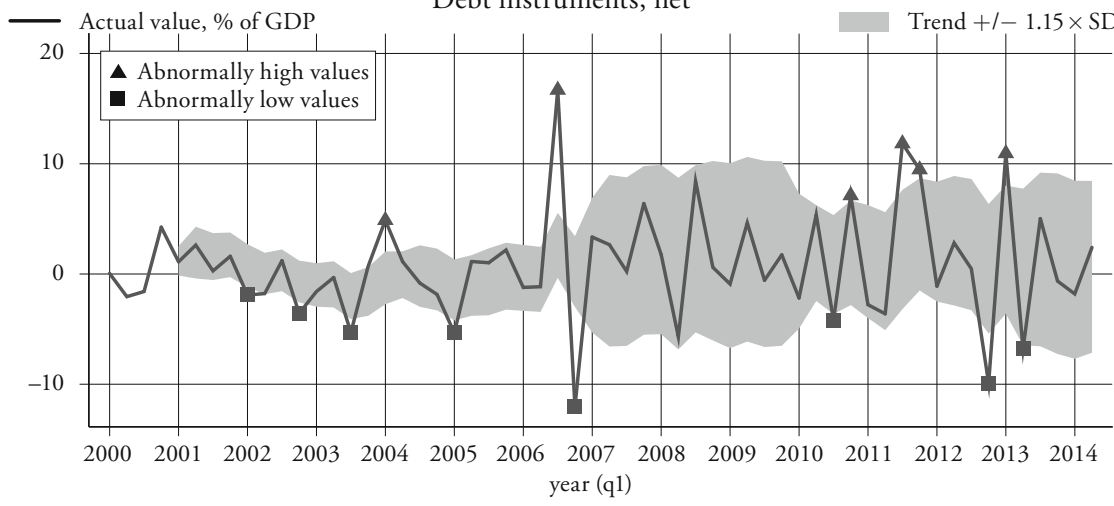

Source: SNB and author's calculations. 
Figure B6: Portfolio Investment Flows (\% of GDP)

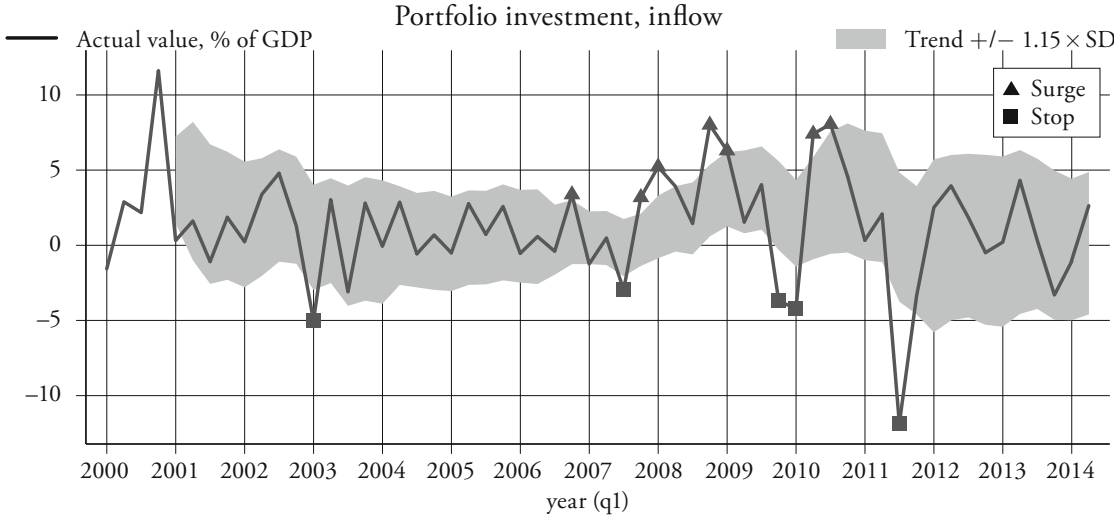

Portfolio investment, outflow

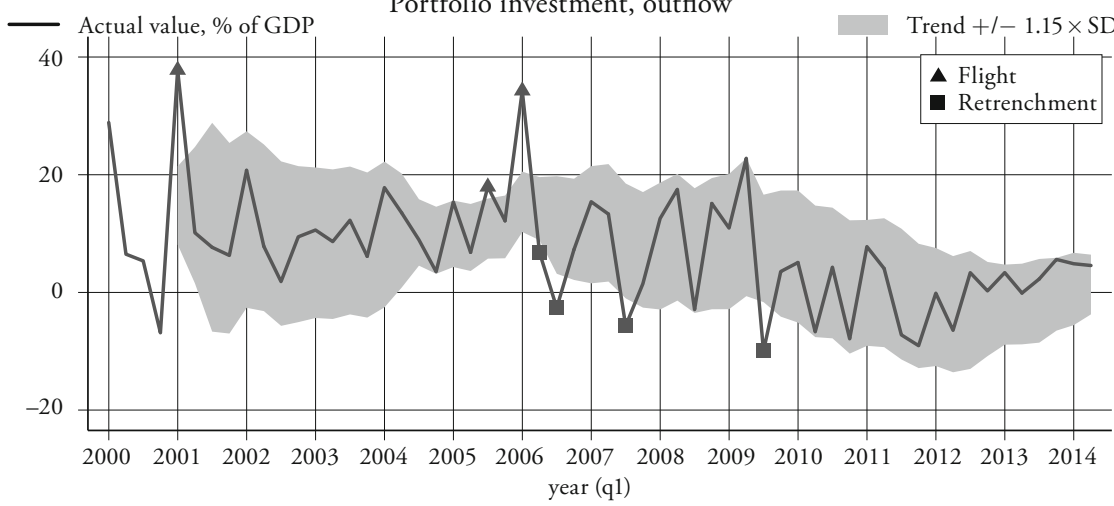

Portfolio investment, net

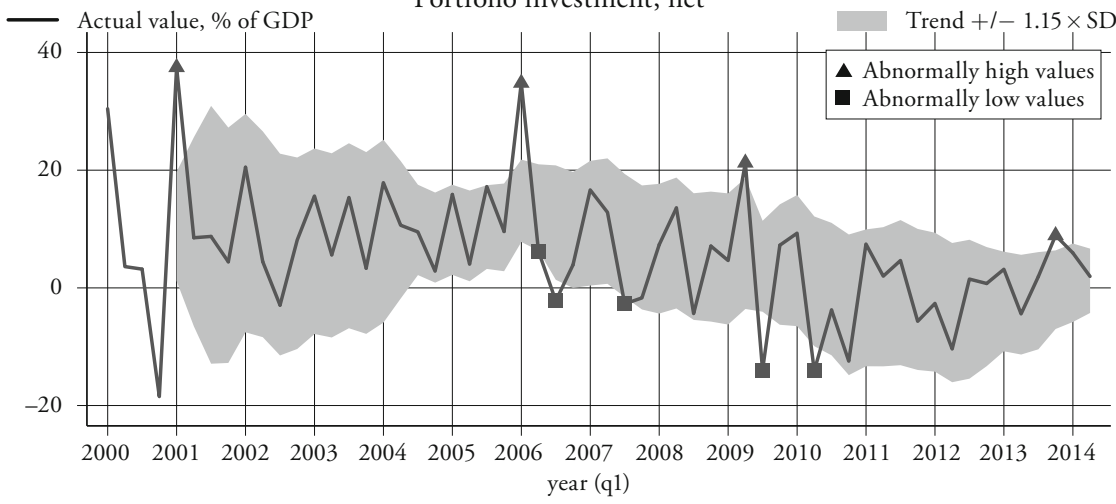

Source: SNB and author's calculations. 


\section{Figure B7: Debt Securities Flows (\% of GDP)}

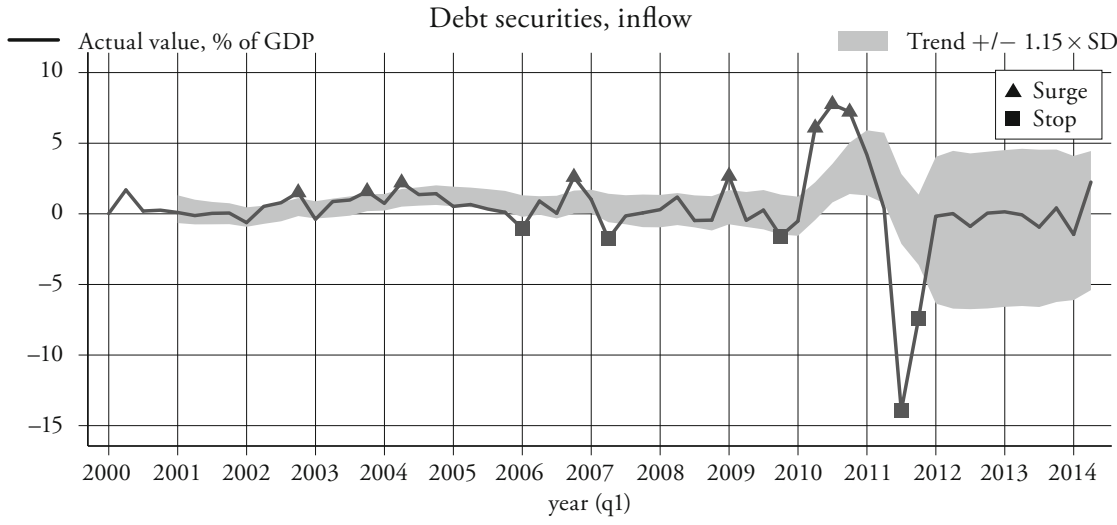

Debt securities, outflow

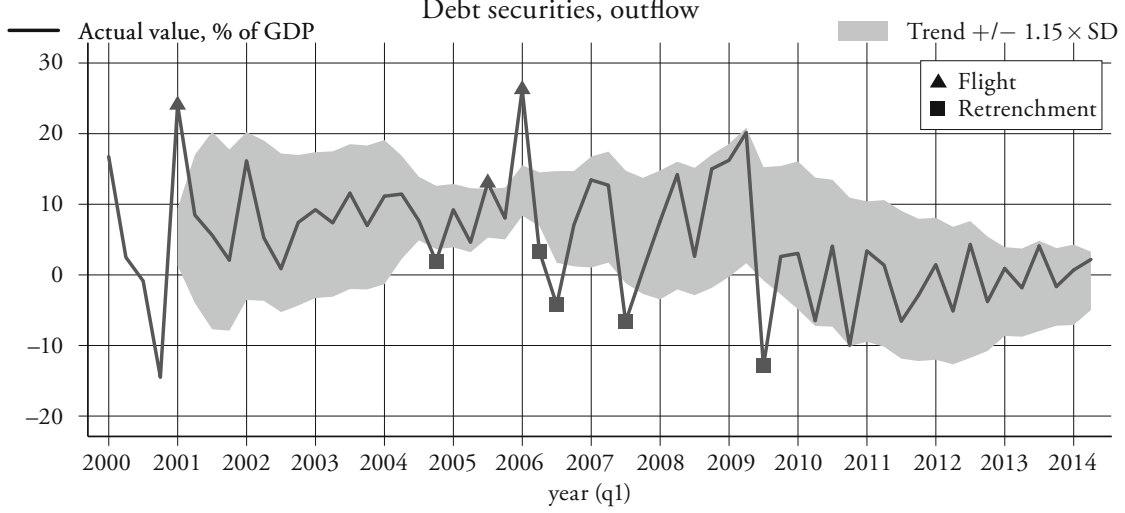

Debt securities, net

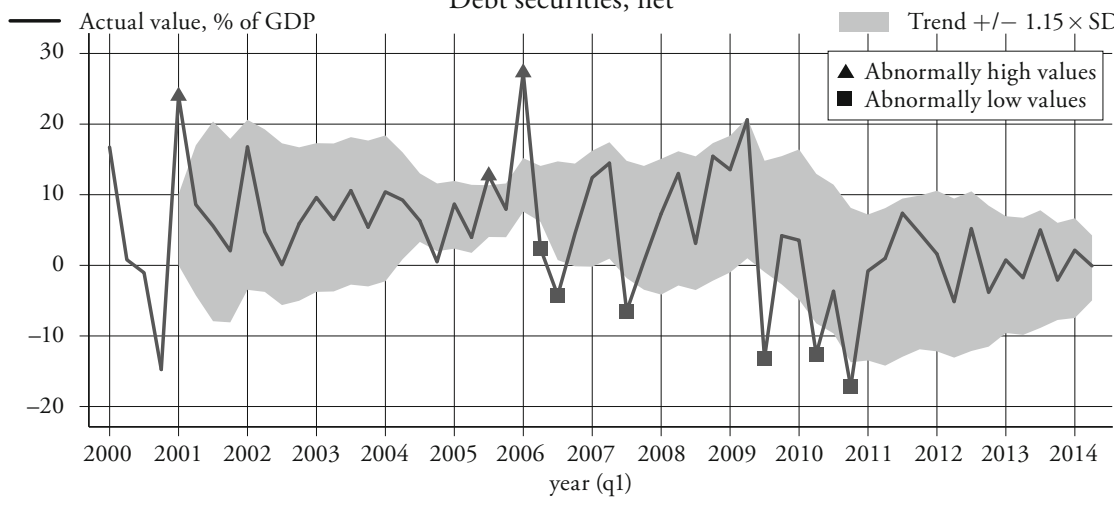

Source: SNB and author's calculations. 
Figure B8: Equity Securities Flows (\% of GDP)

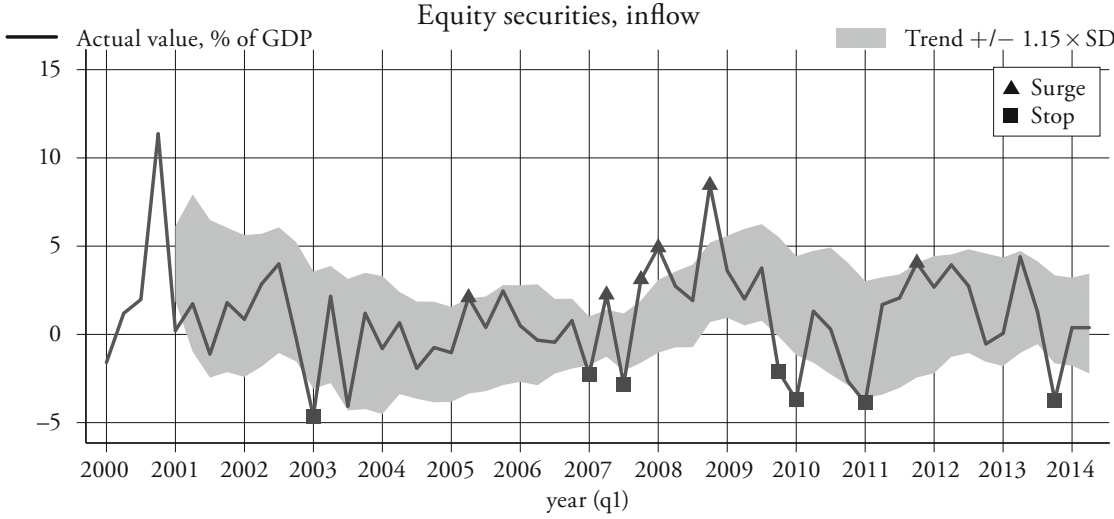

Equity securities, outflow

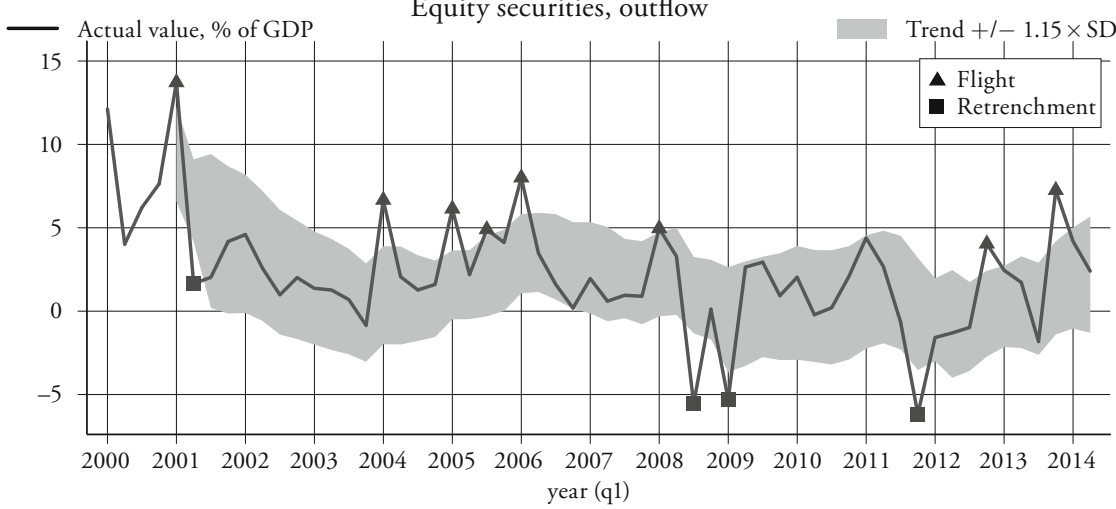

Equity securities, net

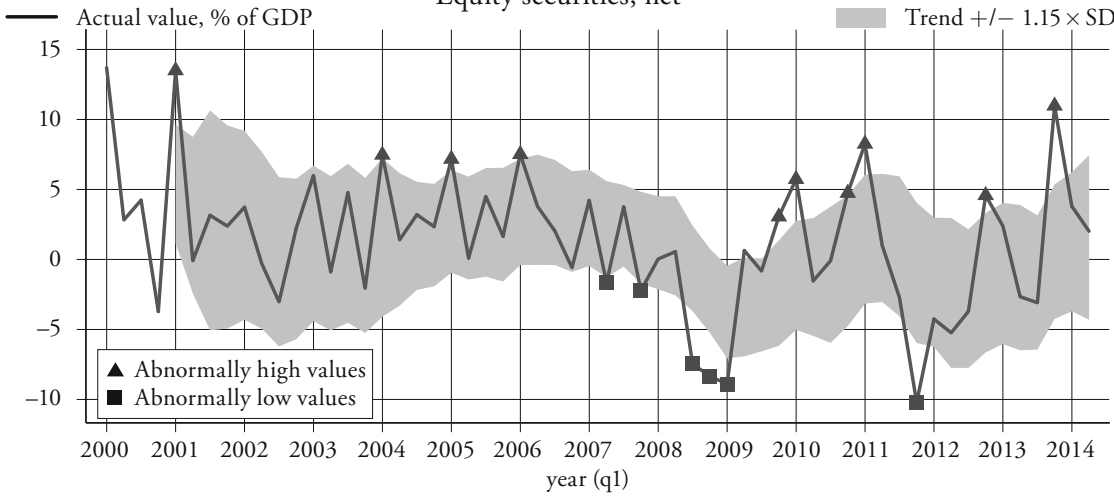

Source: SNB and author's calculations. 
Figure B9: Other Investment Flows (\% of GDP)
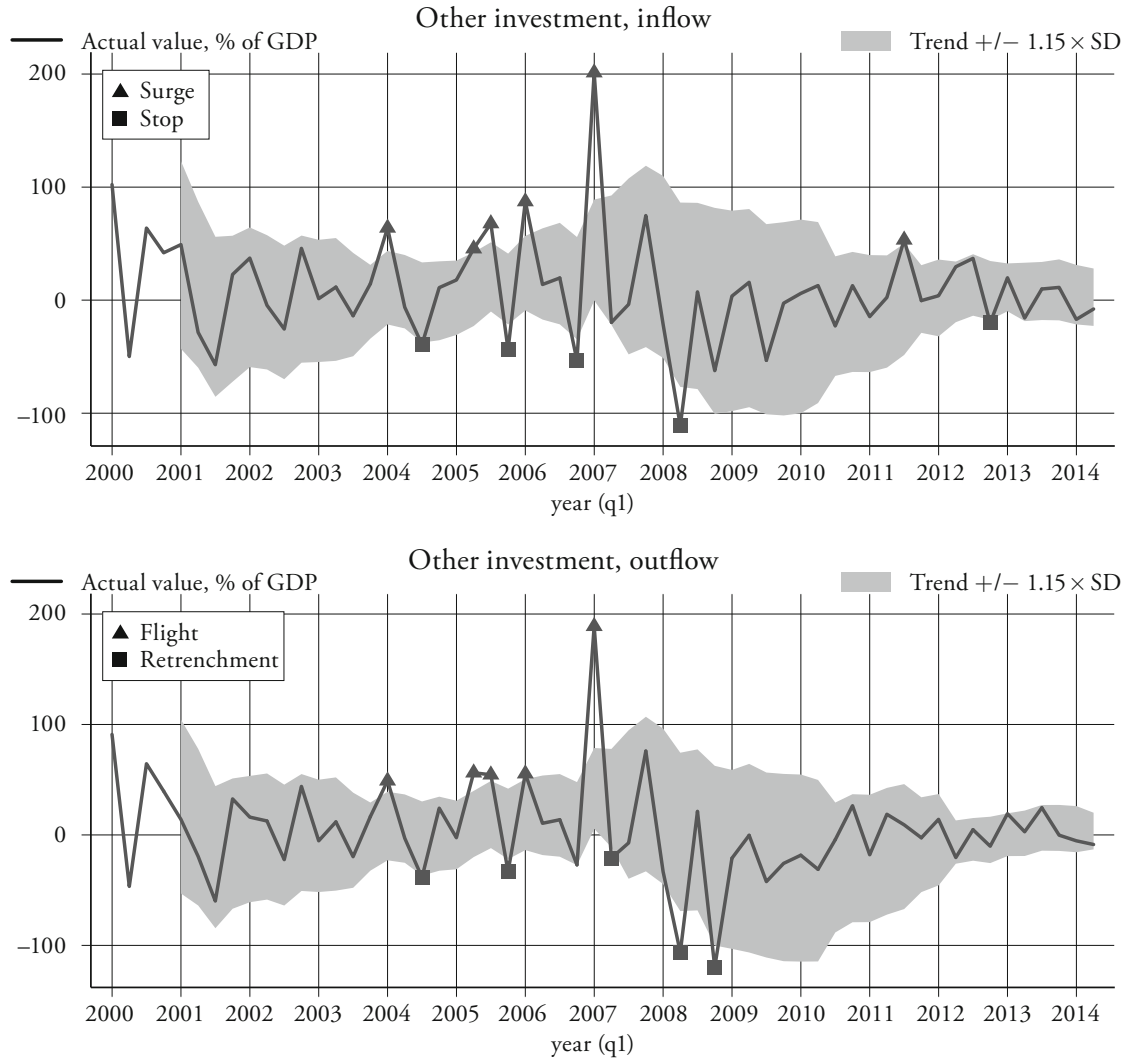

Other investment, net

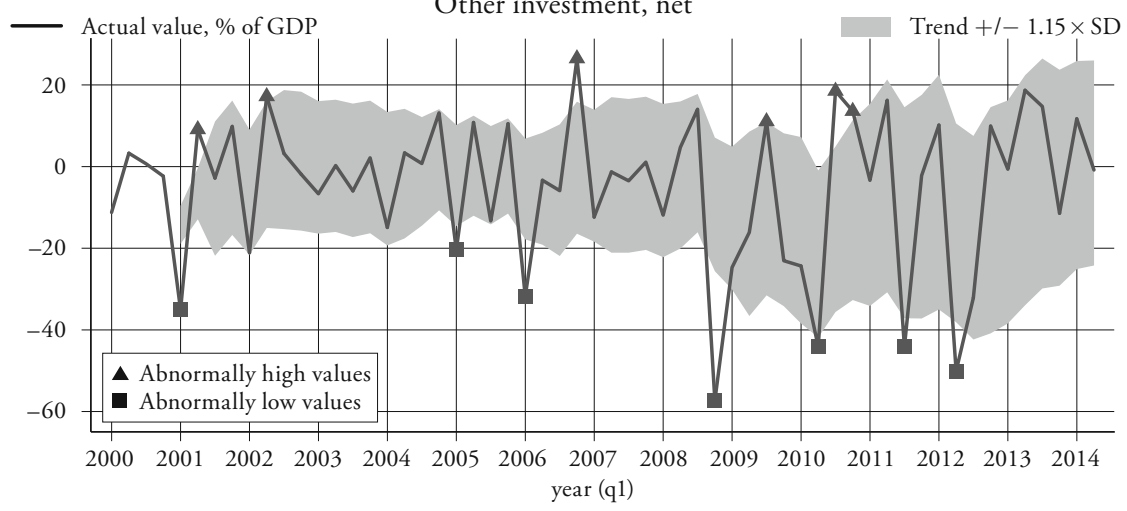

Source: SNB and author's calculations. 
Figure B10: Bank Lending Flows (\% of GDP)
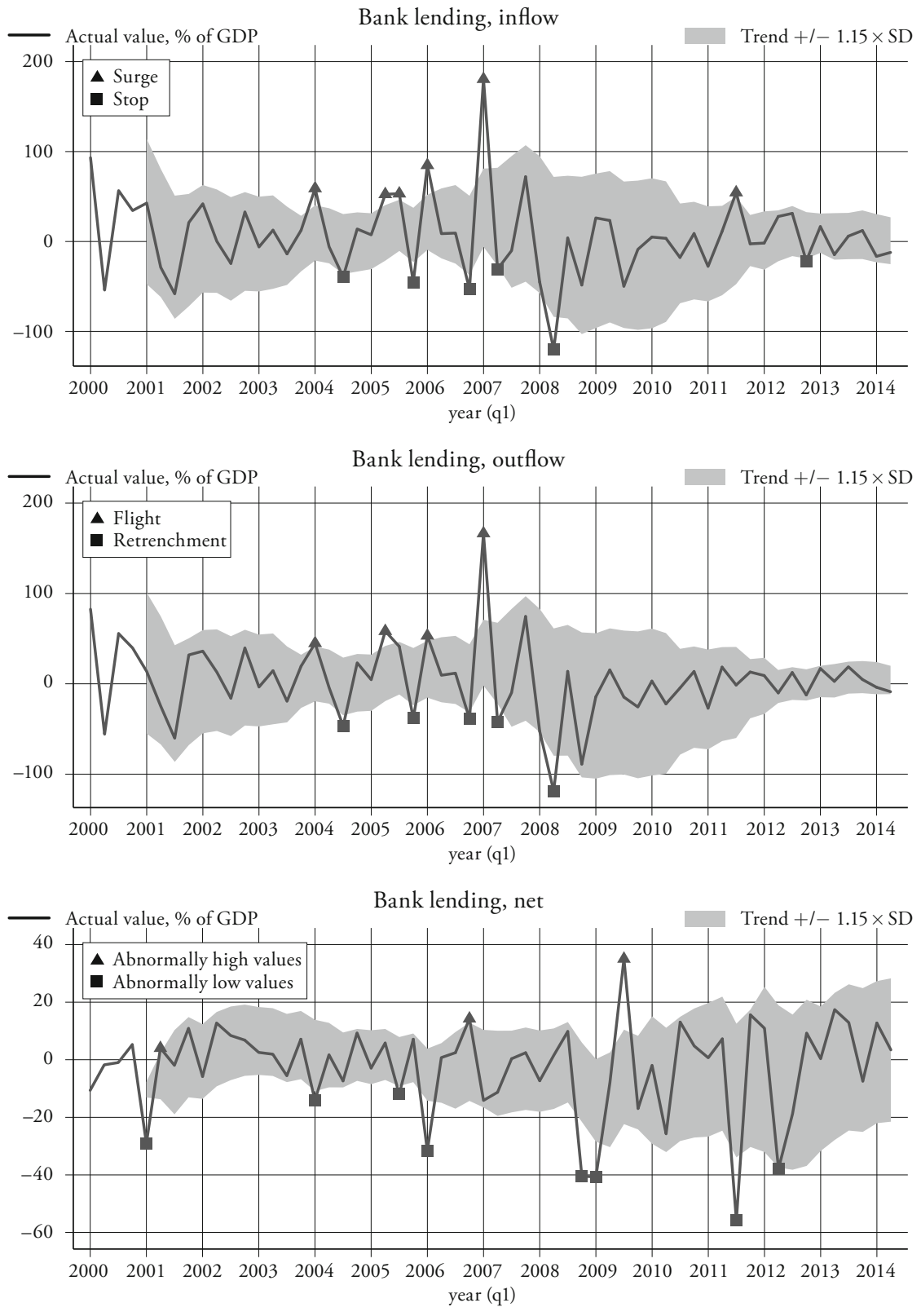

Source: SNB and author's calculations. 
Figure B11: Other Sectors Lending Flows (\% of GDP)

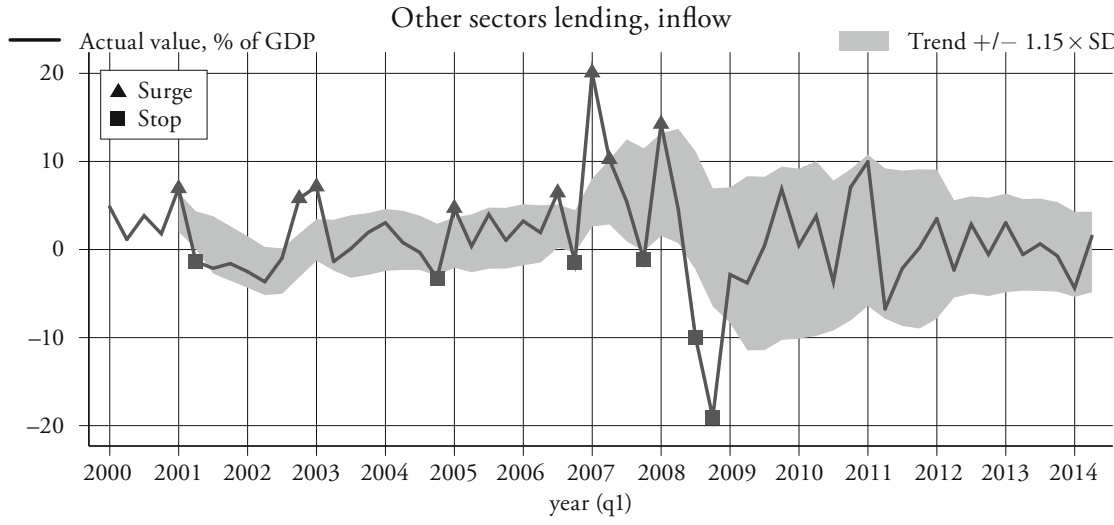

Other sectors lending, outflow

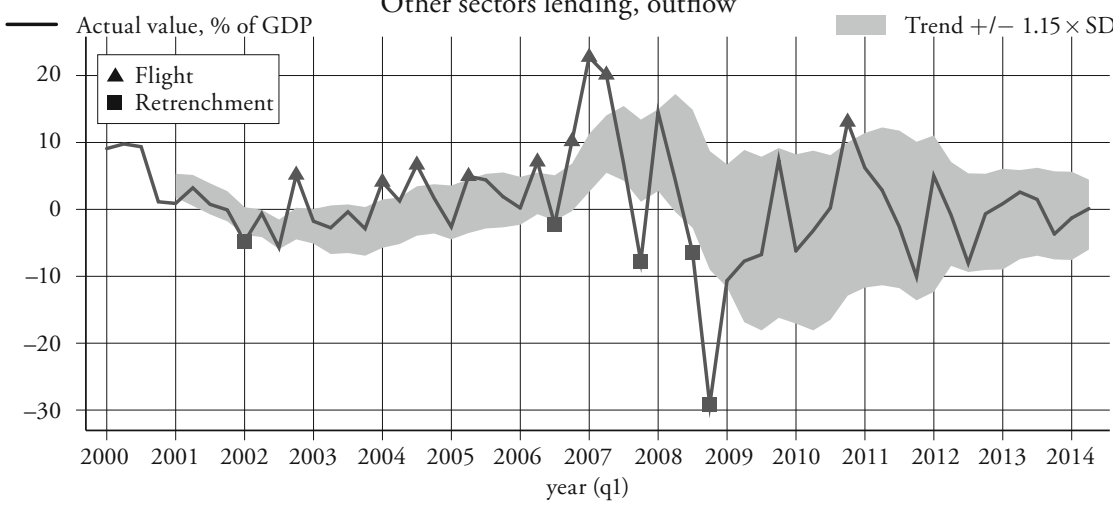

Other sectors lending, net

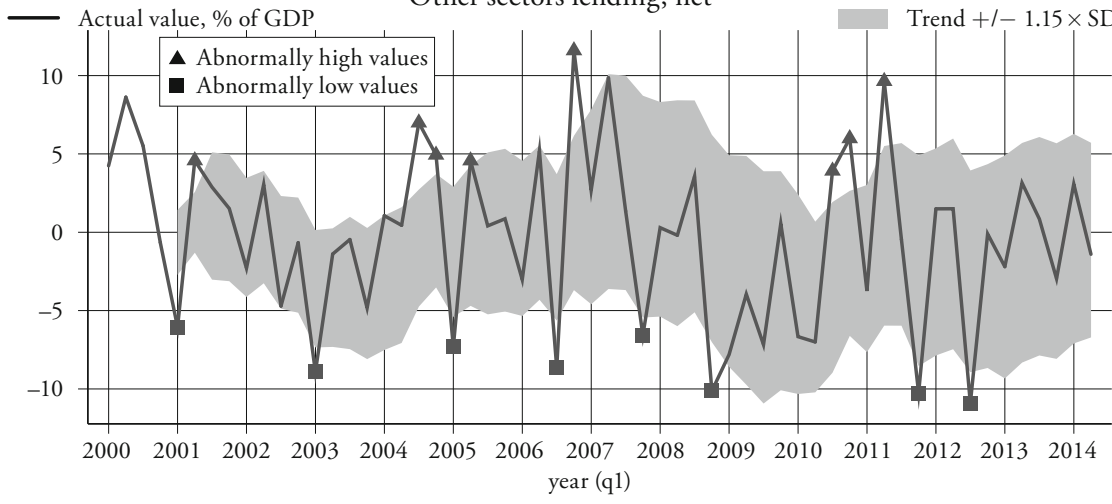

Source: SNB and author's calculations. 
Figure B12: Reserve Assets Flows (\% of GDP)

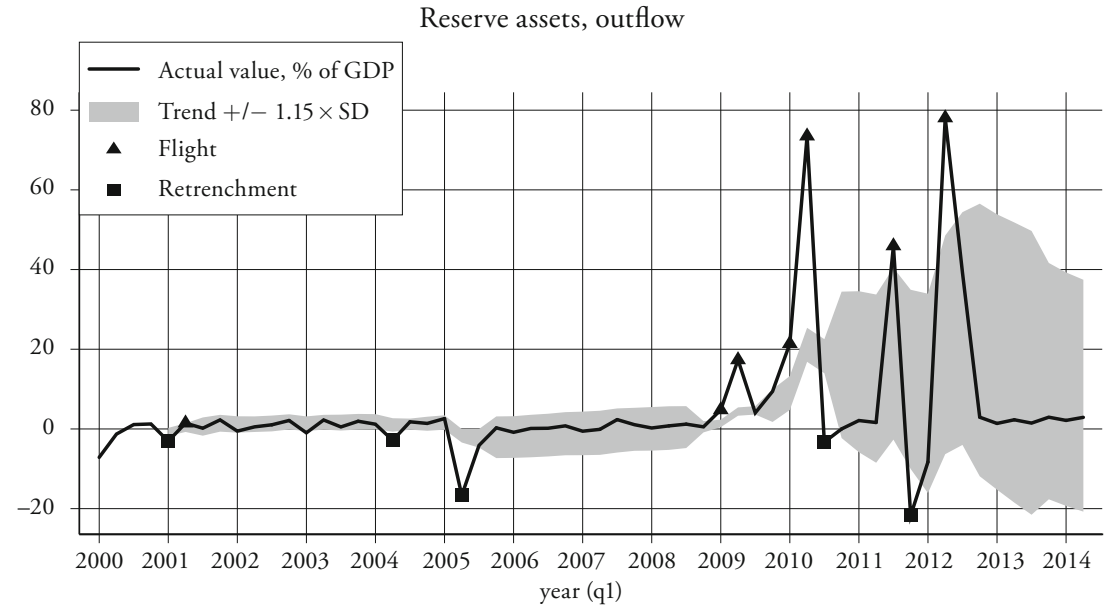

Source: SNB and author's calculations.

Figure B13: Foreign Currency Investment Flows (\% of GDP)

Foreign currency investment, outflow

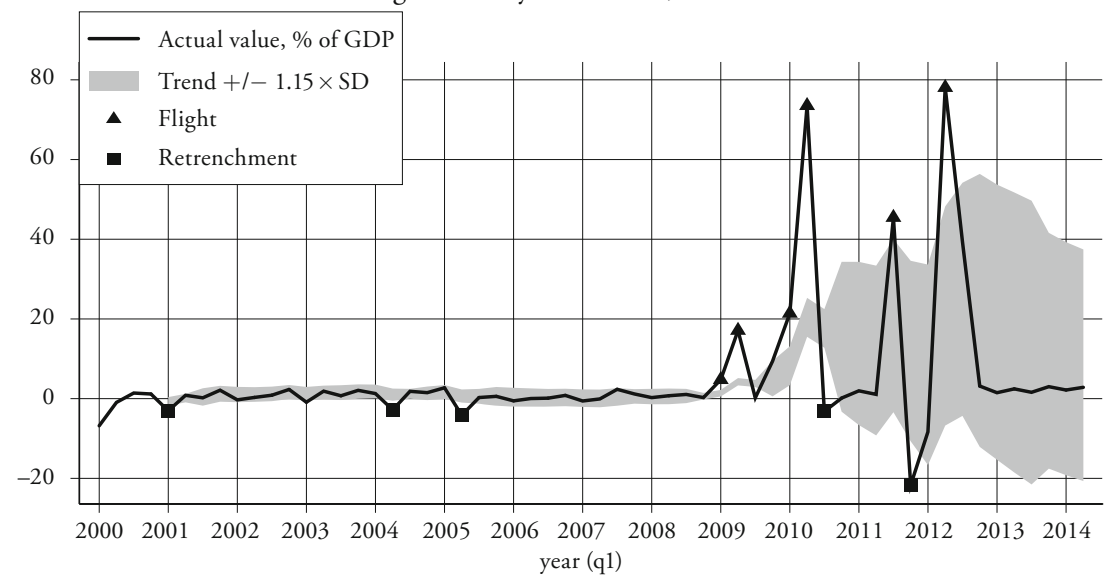

Source: SNB and author's calculations. 
Figure B14: Derivatives Flows (\% of GDP)

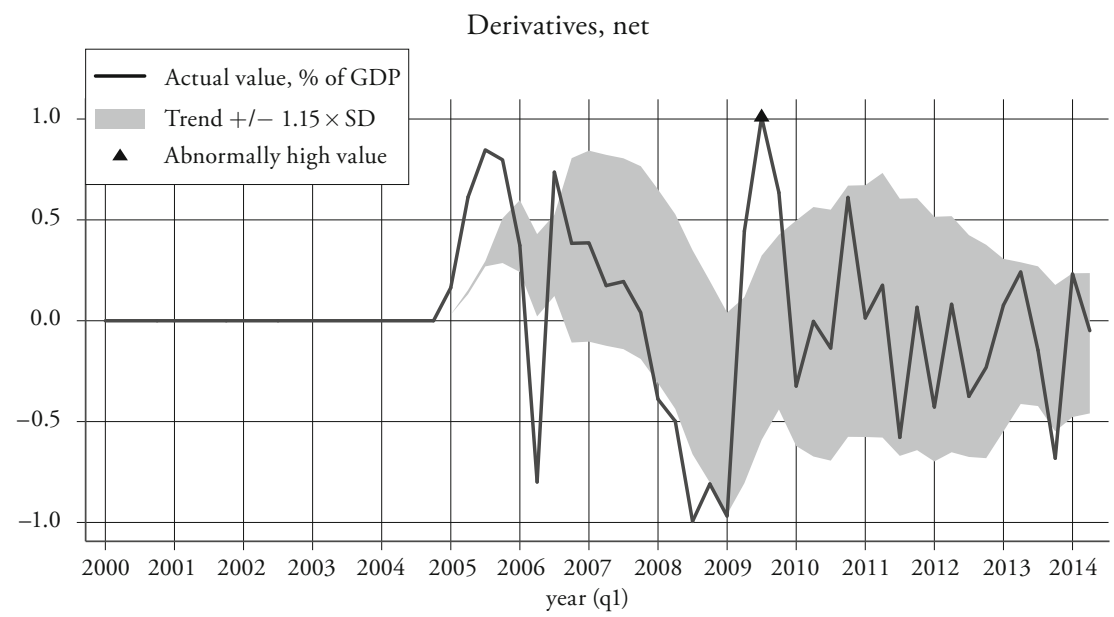

Source: SNB (BPM6) and author's calculations.

\section{References}

Ahmed, Shaghil, and Andrei Zlate (2014), "Capital Flows to Emerging Market Economies: A Brave New World?", Journal of International Money and Finance, 48(B), pp. 221-248.

Bluedorn, John, Rupa Duttagupta, Jaime Gujardo, and Petia Topalova (2013), "Capital Flows Are Fickle: Anytime, Anywhere", IMF Working Paper, No. 13/183, International Monetary Fund.

Broner, Fernando, Tatiana Didier, Aitor Erce, and Sergio L. SchmukLER (2013), "Gross Capital Flows: Dynamics and Crisis", Journal of Monetary Economics, 60(1), pp. 113-133.

Calvo, Guillermo (1998), "Capital Flows and Capital-Market Crises: The Simple Economics of Sudden Stops", Journal of Applied Economics, 1(1), pp. 35-54.

Cardarelli, Roberto, Selim Elekdag, and M. Ayhan Kose (2010), "Capital Inflows: Macroeconomic Implications and Policy Responses”, Economic Systems, 34(4), pp. 333-356.

Forbes, Kristin J., and Francis E. Warnock (2012a), "Capital Flow Waves: Surges, Stops, Flight, and Retrenchment”, Journal of International Economics, 88(2), pp. 235-251. 
Forbes, Kristin J., and Francis E. Warnock (2012b), "Debt- and Equity-Led Capital Flow Episodes”, NBER Working Paper Series, No 18329, National Bureau of Economic Research.

Furceri, Davide, Stéphanie Guichard, and Elena Rusticelli (2012), "The Effect of Episodes of Large Capital Inflows on Domestic Credit", The North American Journal of Economics and Finance, 23(3), pp. 325-344.

Ghosh, Atish R., Mahvash S. Quereshi, Jun Il Kim, and Juan Zalduendo (2014), "Surges", Journal of International Economics, 92(2), pp. 266-285.

Kraay, Aart, Norman loayza, Luis Servén, and Jaume Ventura (2005), "Country Portfolios", Journal of the European Economic Association, 3(4), pp. 914-945.

Lane, Philip (2013), "Capital Flows in the Euro Area", CEPR Discussion Paper Series, No. 9493.

Lane, Philip R., and Gian Maria Milesi-Ferretti (2007), "Capital Flows to Central and Eastern Europe”, Emerging Markets Review, 8(2), pp. 106-123. Milesi-Ferretti, Gian Maria, and Cedric Tille (2011), "The Great Retrenchment: International Capital Flows during the Global Financial Crisis", Economic Policy, 26(66), pp. 285-342.

Powell, Andrew, and Pilar Tavella (2012), "Capital Inflow Surges in Emerging Economies: How Worried should LAC Be?”, IDB Working Paper Series, No. IDB-WP-326, Inter-American Development Bank.

Reinhart, Carmen M., and Vincent R. Reinhart (2008), "Capital Flow Bonanzas: An Encompassing View of the Past and Present", NBER Working Paper Series, No. 14321, National Bureau of Economic Research.

Tillmann, Peter (2013), "Capital Inflows and Asset Prices: Evidence from Emerging Asia”, Journal of Banking and Finance, 37(3), pp.717-729.

\section{SUMMARY}

This paper first shows that capital inflows to and outflows from financial centers were disproportionately affected by the global financial crisis. Switzerland was no exception. The paper then identifies waves of capital flows to and from Switzerland from 2000:Q1 to 2014:Q2 by using a simple statistical method. The analysis shows that private capital inflows to and outflows from Switzerland have become exceptionally muted and less volatile since the crisis. Further, strong and long-lasting 'home bias' behavior can be observed for both Swiss and foreign investors. By contrast, net private capital flows have shown significantly higher volatility since the financial crisis, frequently registering extreme 
movements driven by extreme movements in bank lending flows. These findings suggest that the financial crisis generated a breaking point for capital flows to and from Switzerland. 